\title{
How Agriculture Took Hold in the Mesa Verde Region: A Review of Recent Research on the Late Basketmaker-Early Pueblo Periods (A.D. 500-920)
}

\author{
Richard H. Wilshusen \\ Paleocultural Research Group
}

\begin{abstract}
Major research projects and significant publications over the last two decades have fundamentally reframed our understanding of the Basketmaker III and Pueblo I periods in the Mesa Verde region. Whereas the last state historic context summaries for these periods, which were published in 1999, focused on the specifics of chronology building, site type definitions, settlement patterning, and other nuts and bolts issues, recent advances in database software and an increasing emphasis on regional research have turned our attention to the larger issues of how agriculture took hold and thereafter transformed the landscape north of the San Juan River. The relatively low populations and small-scale horticultural economies of the Basketmaker II period virtually disappeared between A.D. 500 and 600, to be replaced by a more intensive maize-dependent agricultural economy centered on large communities. The rapid expansion of early Pueblo agricultural settlements across the Mesa Verde region and the subsequent formation of large villages were in part fueled by the accelerating population growth that came with agricultural dependence. In turn, the late ninth-century breakup of these large villages contributed to population migration to the south of the San Juan River and the tenth-century emergence of what ultimately became the Chaco great house system. This review updates the 1999 Basketmaker III and Pueblo I overviews.
\end{abstract}

Keywords: Basketmaker III; Pueblo I; early villages; Neolithic agriculture; migration

As archaeologists, it can be challenging to keep up with the onslaught of current research as we work to finish our own reports. This is not a new dilemma. More than 40 years ago, Alden Hayes and James "Al" Lancaster registered their painful awareness of all that had been learned in the decade between the completion of their Mesa Verde fieldwork and the publication of their Badger House report in 1975. Similarly, in the almost two decades since the publication of the Southern Colorado River Basin context (Lipe et al. 1999), there have been tremendous advances in our understanding of the Basketmaker III (A.D. 500-750) and Pueblo I (A.D. 750-900) periods within this context area (figure 1). Yet, in this case I am gratified that many of the research recommendations in that volume (Wilshusen 1999a:192-195; Wilshusen 1999b:239241) have been realized and that the research summaries are now in serious need of an update.

The 1999 research recommendations were written at a time when the first user-friendly relational database software programs were just beginning to be more widely used by archaeologists and when the results of the massive Dolores Archaeological Project (DAP) were becoming more readily available in regional and national professional journals (e.g., Breternitz 1993; Kohler 1993; Lightfoot 1988; Schlanger 1988; Wilshusen and Ortman 1999). The results (and shortcomings) of the Dolores research, along with previous work 


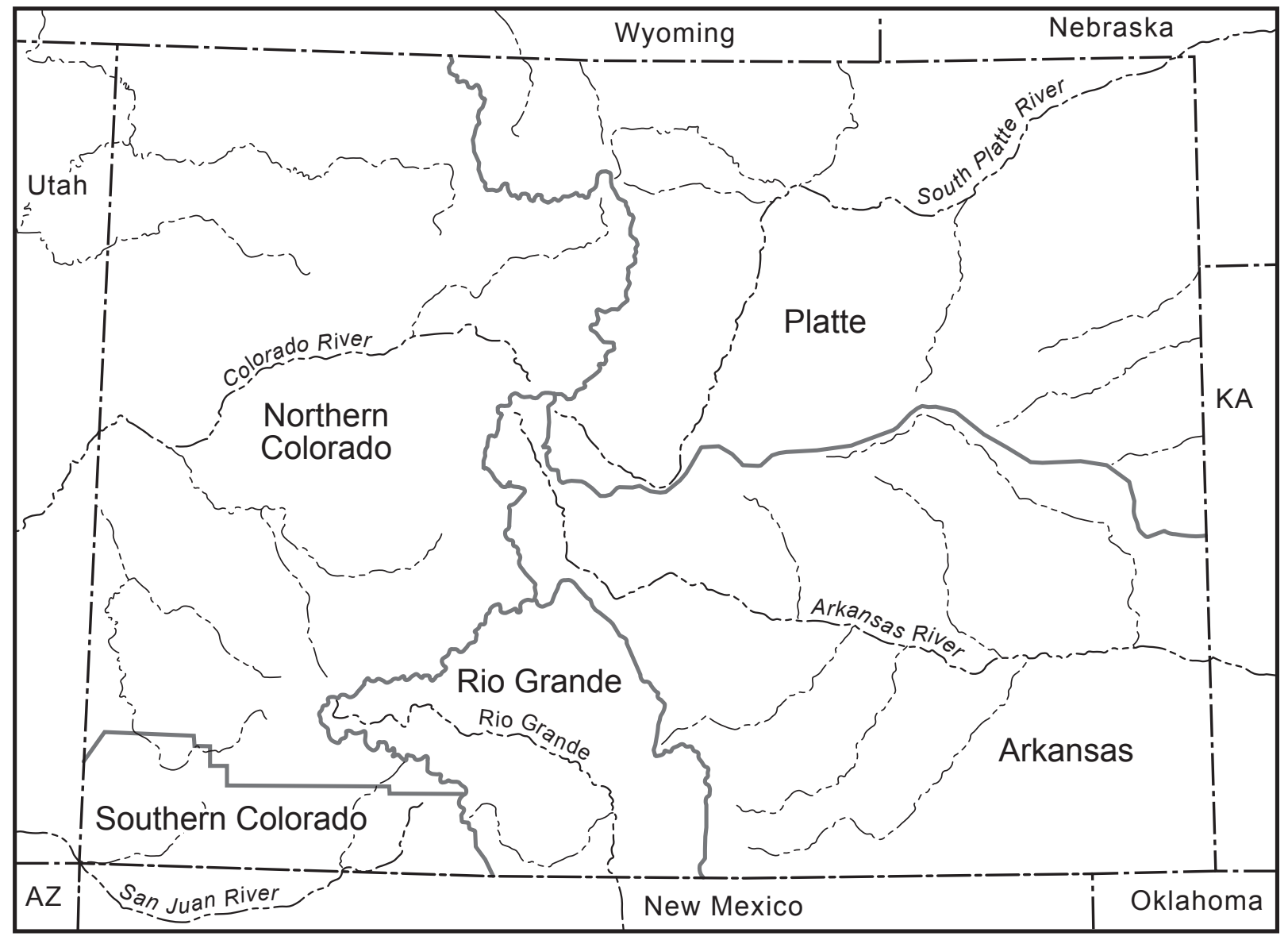

Figure 1. The Southern Colorado context area in relation to the other four historic context areas, as defined in 1999. Adapted from Lipe 1999:Figure 1-1.

on Mesa Verde (e.g., Birkedal 1976; Hayes and Lancaster 1975) and survey work in the greater Mesa Verde region (Fetterman and Honeycutt 1987; Wilshusen and Wilson 1995), shaped many of the suggestions I made for future research. Although the recommendations are often cited as starting points in the research I discuss below, in large measure those proposals are now as outdated as the computer and the software I used in 1999. They have served their purpose.

In this review, I offer a snapshot of some of the most important mitigation projects and the more far-reaching collaborative research and heritage management projects that have taken place over the past nearly two decades. The late Basketmaker-early Pueblo time span has become the focus of renewed attention over the last fifteen years, resulting in key texts that offer a more comprehensive view of the period. Southwestern archaeologists have increasingly accepted that the Neolithic "revolution" (Childe 1951) first recognized in the Old World was equally "revolutionary" in terms of the social, economic, and ecological changes it engendered in the New World. Additionally, we have realized that some of the best data we have in the world to understand the early Neolithic demographic transition, human adaptation to climate change, and other challenges that accompanied the agricultural revolution are found in the Southwest's archaeological record. The highly refined chronology of the "Mesa Verde region" (a more comprehensive term I will use hereafter in place of the "Southern Colorado River Basin area") allows us the rare opportunity to understand this period of revolutionary change at almost a generational level of temporal precision.

Yet, the last decades have also brought an astonishing loss of much of the "historic fabric" of 
the late Basketmaker and early Pueblo periods in the Mesa Verde region. The irrigation of fields, energy development, and an increase in the number of rural homes have altered or erased significant portions of what remained of the ancient agricultural landscape of the region. These losses have made the research of the last decades all the more vital. A forthcoming contribution to Reviews in Colorado Archaeology will build on this review and suggest ways we might balance site-specific preservation and mitigation priorities with region-wide heritage management and preservation issues to reduce the effects of this landscape loss. In addition, the forthcoming article will propose changes to the context area and the period chronologies, as well as offer a set of new research themes for future work, with an eye toward updating the 1999 research recommendations.

This review should be seen as an introduction to a rich array of new research. I hope that this article engenders an online discussion and encourages others to provide summaries of recent investigations that I am unable to mention in this review. I urge others to use the ORCA User Forum, Research Library, or Research Links to add to this synthesis or to offer alternative interpretations of these data.

The article is broken down by specific research projects or topics and is ordered so as to best tell the story of the dramatic changes in the Mesa Verde region during this period. As discussed below, regional population fluctuations in this area were remarkable: the population went from practically zero (A.D. 500) to more than 12,000 (A.D. 850) and then plummeted to possibly as low as 2,500 people in the mid-to-late tenth century. These four centuries truly were a period of transformation and a key turning point in Pueblo history.

\section{Late Basketmaker Research: The Beginnings of Basketmaker III, The Basketmaker Communities Project, and Surprises}

Southwestern archaeologists formally defined the Basketmaker culture in 1927 when they created the Pecos classification as a method of dividing up Southwestern prehistory. Beginning with the historic Pueblos (called Pueblo V), it traced the development of Pueblo culture back to the time of the very first pueblos (Pueblo I) and listed expected material culture traits and changes for each stage of development. The time prior to pueblos, when households lived in pithouses and primarily used basketry, was called Basketmaker, and it had three proposed stages of development, beginning with a hypothesized Basketmaker I and ending with Basketmaker III. The Pecos system was created before archaeologists had the means to determine the age of a site through methods such as tree-ring dating or radiocarbon dating.

Many of the Pecos classification periods (or stages, as they were originally conceived) do not have clear-cut beginnings and endings, but a real division does seem to exist between the end of Basketmaker II and the beginning of Basketmaker III. The interim between the two periods is a century-long all-but-blank slate in the history of the Mesa Verde region. Basketmaker II ends with a whimper between A.D. 400 and 500. Only a very limited number of habitation sites have been identified for this century: in the Navajo Reservoir area (Hovezak and Sesler 2006), a portion of the cemetery at the Darkmold site north of Durango (Charles 2011), and a few other sites scattered across the region. Most researchers accept that there was a widespread withdrawal of the population from the Mesa Verde region throughout much of the sixth century, but no single explanation-climate change, the depletion of wild resources, social strife, or a major shift in adaptive strategies-adequately explains this withdrawal. The diversity within Basketmaker II groups, with clear distinctions between those centered in the Durango and Navajo Reservoir areas in the east and a variety of western groups in the Cedar Mesa and Bears Ears area and farther west, makes any overarching explanation problematic.

Although these early eastern and western Basketmakers were dependent over many years on a diet rich in maize (Coltrain et al. 2006, 2007; Matson and Chisholm 1991), specific subsistence strategies and horticultural practices (Bellorado 2011; Matson 2003; Sesler and Hovezak 2011) appear to have differed among the Basketmaker II groups. Each inhabited a sufficiently unique environment that no single subsistence strategy would have sufficed. In Durango, many of the early Basketmaker habitations were near alluvial fans associated with hillsides or in alcoves above perched valleys or the river valley, with easy access to large- and medium-sized 
mammals. In the Navajo Reservoir area, the sites were at lower elevations, with less precipitation and greater reliance on medium-sized and small game. And on Cedar Mesa, the habitations were focused on locales more conducive to a mix of floodwater horticulture, hunting, and foraging.

Researchers have variously described early Basketmakers as forager-farmers, farmer-foragers, or simply farmers; yet the diverse faunal, floral, site location, and architectural evidence for various Basketmaker II groups indicates that they more appropriately could be called horticulturalists. They lived in various settings where large gardens of corn, squash, and ruderal plants were possible, but the archaeological evidence shows that wild game, plants, fruits, seeds, and nuts were still a significant part of their diet. Although many sites had storage cists of sufficient size and number to have allowed year-round storage of corn, others show limited evidence of long-term storage facilities or facilities that were so ephemeral in construction as to be difficult to detect in the archaeological record. If we think of Basketmaker II peoples as horticulturalists, the variation in the records from these disparate sites becomes much more coherent. They ate corn regularly, but they also still had relatively low population densities and relatively easy access to wild resources.

In contrast, there's a greater uniformity to the habitation locales of the seventh-century communities; these people can only be described as farmers. Although they encouraged an assortment of ruderal plants, collected wild resources, hunted all kinds of game, and fell back on foraging in dire times, the fact that we often find early Basketmaker III habitation sites in the middle or at the edge of modern agricultural fields betrays these people's identity as farmers (figures $2 \mathrm{a}$ and $2 \mathrm{~b}$.). Recent studies offer substantial evidence that in-migration into the central portion of the Mesa Verde region must have augmented the intrinsic growth of early seventh century farming communities such as the Dillard site (Diederichs 2016; Ortman et al. 2016). This population growth, as well as the adoption of new subsistence technologies (Kohler and Glaude 2008; Kohler and Varien 2010; Ortman 2006) such as pottery, beans, and starchy varieties of maize, helped to accelerate the shift to greater agricultural dependence throughout the region.

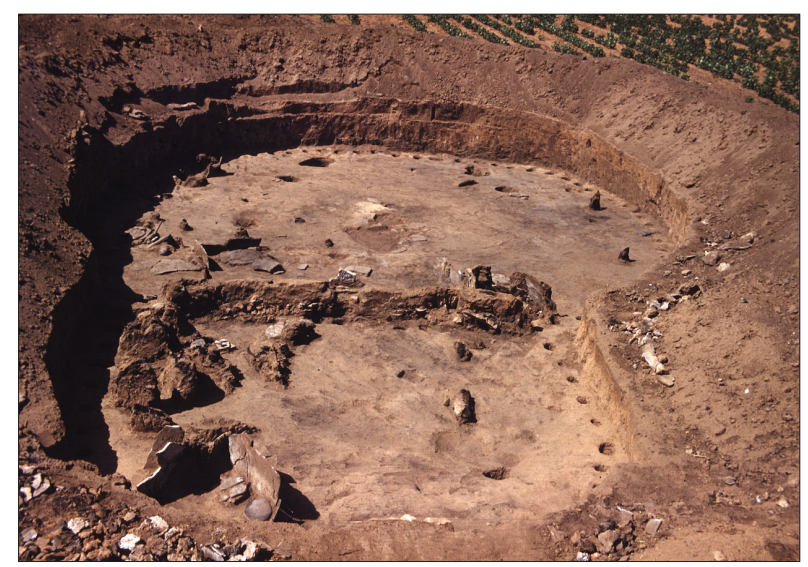

Figure 2a Excavation photo of Pit Structure 3, Stevenson site (5MT1), an oversized Basketmaker III house constructed ca. A.D. 676. Note the pinto bean field obvious in the upper right corner of the photo. Image is from Mitchell 2005 (SL-YJ-001) and is reproduced by permission. Copyright University of Colorado Museum of Natural History.

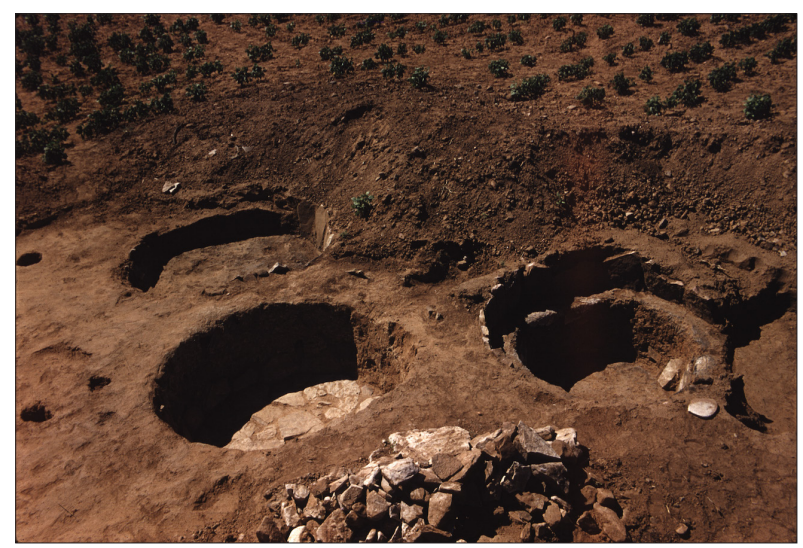

Figure 2b. Excavation photo of Pit rooms 1.06, 1.07, and 1.08, Stevenson site (5MT1), food storage facilities. Image is from Mitchell 2005 (SL-YJ-034) and is reproduced by permission. Copyright University of Colorado Museum of Natural History.

When you look at excavation photos of Basketmaker III habitation sites, you are likely to see corn, bean, or wheat fields in the background (Chenault et al. 2004; Mitchell 2005). It can sometimes be difficult to detect the prehistoric ground surfaces and the surrounding features, such as encircling fences or stockades, at these sites because of the many decades of modern cultivation. 
Although no one to my knowledge has measured the significance of the association, there appears to be a striking correspondence between the soils, settings, and elevations selected for historic farms and where late Basketmaker habitations are found. I have even encountered, on survey, an area with surprisingly low prehistoric habitation site density that was later explained by a local bean farmer as being a field with a low appraisal value because of its exceptionally high risk of crop loss due to seasonal hail or frost damage. These ancient farmers knew the contours of these landscapes.

In the 1999 context, I failed to appreciate the rapid population growth in these new farming populations and the surprising increase in the complexity of the local community centers that were created. Studies such as Mitchell's (2005) write-up of Joe Ben Wheat's 1954-1957 excavations of the Stevenson site serve to remind us of the magnitude of these early multi-household Basketmaker III residential sites. A clearly defined, contiguous arc of more than 10 storage rooms bounded each of the two immense pithouses at that site (figure 3). One of the pithouses (Pit Structure 3) had a floor area of approximately $102 \mathrm{~m}^{2}$, an area larger than a typical great kiva might have, even though this structure appears to have functioned primarily as a residence (see figure 2a). The entire site appears to have been built at or soon after A.D. 676, with two smaller potentially contemporaneous pithouses built just to the east of the largest residence mentioned above.

Although I had referenced and discussed the large Basketmaker III habitation sites that have two or more pithouses in my earlier work (Wilshusen 1999a:177), it took the later careful compilation and examination of 62 Basketmaker III pit structures (Wilshusen, Ortman, and Phillips 2012:199-204) to demonstrate that these same large pithouses very likely served as gathering places for local ritual performance. Their large size, the occurrence of special ritual features at these same sites, and extramural features such as stockades or fences (Chenault and Motsinger 2000) all point to greater Basketmaker III investment in community centers, integration of locales, and competition among local community leaders than I could have ascertained from what was known in 1999.

Recent studies have roundly refuted my

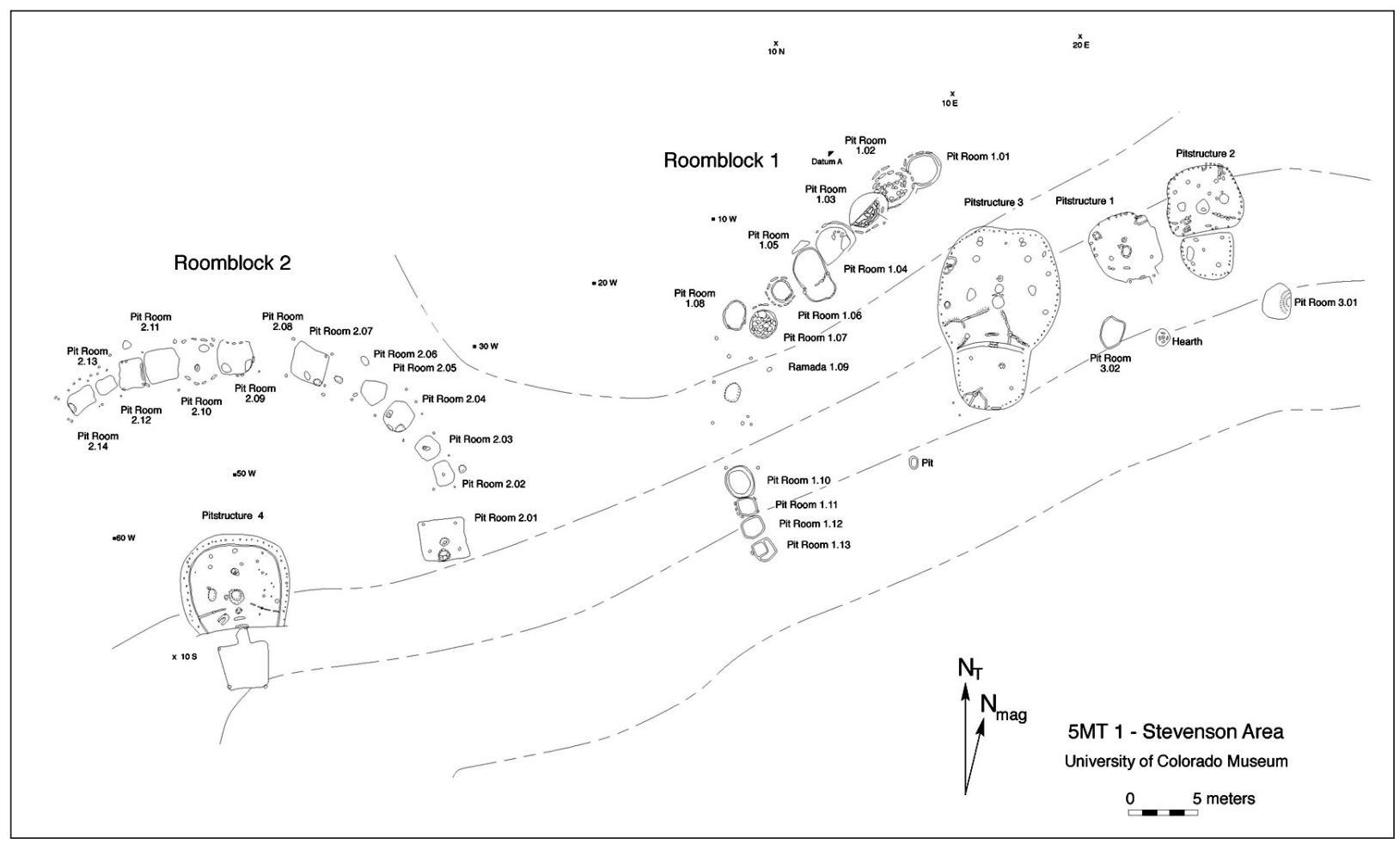

Figure 3. Plan map of Stevenson site (5MT1). Image is from Mitchell (2005) and is reproduced by permission. Copyright University of Colorado Museum of Natural History. 
assertions that public architecture, such as villages and great kivas or dance circles, was lacking in the context area during this period (1999a:175177). Crow Canyon's innovative Basketmaker Communities Project and their excavations at the Dillard site (5MT10647) have transformed and expanded my conception of early community centers. Although I accepted that large hamlets and their stockades could have served as focal points and defensive redoubts for a community in dire times, I did not anticipate that we would find such a large and complicated early community center such as the Dillard site (figure 4). Dillard is three to four times larger in size and numbers of structures than the largest multi-household hamlets, such as the Stevenson site or Dead Dog Hamlet (Chenault

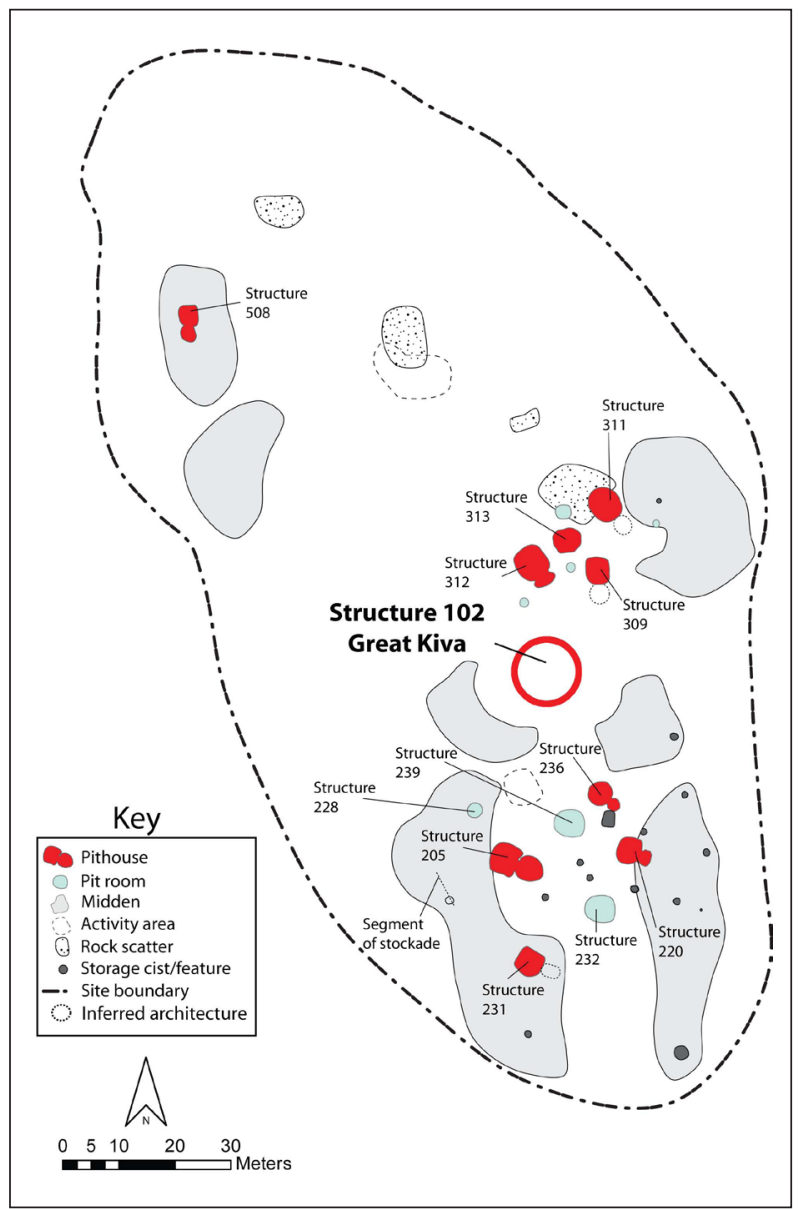

Figure 4. Major cultural units at the Dillard site (5MT10647). Note the $11.5 \mathrm{~m}$-diameter great kiva in the approximate center of the site. Figure is from Sommer et al. 2015 and is reproduced by permission from Crow Canyon Archaeological Center.
2004). Its early to mid-seventh century occupation appears to slightly predate those sites, and its nine to possibly fourteen pithouses, the great kiva at its center, and the large middens that bound the site are a magnitude above the other community centers. At present, the Dillard site is the largest known late Basketmaker residential site in the Mesa Verde region, and it probably is the only candidate for a true pithouse village. It predates the early Pueblo villages in this region by a century or more.

Construction of the great kiva appears to have occurred early in the Dillard site's history, that is, sometime between A.D. 600 and 650, and this act may have served to mediate the cultural differences likely to be found in early colonizer populations (Diederichs 2016). The great kiva would have served as a focal point for rituals incorporating the new settlers and smoothing out differences. The site survey results from the approximately $5 \mathrm{~km}^{2}$ area of real estate development around the Dillard site offer supporting evidence that surrounding hamlets were established later and actually may have contributed to the community center becoming more of a seasonal settlement than a full-time residential center (Ortman et al. 2016). The rapid growth of this surrounding community supports the proposal that higher-than-expected population growth was sustained both by immigration into the region and a high intrinsic growth rate. The early organization of these Basketmaker III communities likely provided the foundation for the increasing concentration of social power seen later in certain early Pueblo villages (Potter and Chuipka 2007; Wilshusen 2017; Wilshusen, Ortman, and Phillips 2012), which will be discussed in the following sections.

Year-end reports and other basic information about the Dillard site and Crow Canyon's continuing work is available on their website (http:// www.crowcanyon.org/index.php/basketmakercommunities-project). At the end of 2018, artifact analyses were underway; a formal site report of the Dillard investigations will be available online when complete. A significant part of Crow Canyon's mission is education, and an episode of the television series Time Team America was entirely devoted to the Dillard investigations and a visit to the site during the 2012 field season (http://www. pbs.org/time-team/explore-the-sites/lost-pueblovillage/). The Dillard site and the sites that comprise 
the district around it (5MT19927) are listed on the National Register as well (Varien and Diederichs 2012). The district nomination and the Dillard site form are available online to archaeologists with Compass access rights through Colorado's Office of Archaeology and Historic Preservation.

Crow Canyon's Basketmaker Communities work on Indian Camp Ranch (ICR) are doubly interesting given that ICR is a real estate development focused on preserving and investigating the prehistory of this area, in a locale only $10 \mathrm{~km}$ north-northwest of Mesa Verde proper. It is an intriguing, and somewhat controversial, attempt to merge professional archaeology, historic preservation, and real estate development into a single endeavor. This and other real estate ventures selling land with "archaeological value" test the bounds of archaeological commercialization and simultaneously offer innovative opportunities for new means to encourage accountability, stewardship, and educational possibilities for excavations on private land. The ICR experiment is ongoing, but Crow Canyon's engagement with ICR on some very important investigations offers archaeologists the opportunity to discuss how much overlap is ethically permissible between real estate sales and historic preservation.

\section{Early Pueblo Research: The Animas-La Plata Project}

The primary research focus of the Animas-La Plata (ALP) investigations focused on sites that immediately post-dated the late Basketmaker period-that is, those dating to approximately A.D. 725-825. The forerunner of the ALP was the DAP, with its main fieldwork undertaken between 1978 and 1985. As noted earlier, the DAP findings substantially shaped the content of the 1999 context chapters on Basketmaker III and Pueblo I. As with the case at Dolores, the ALP investigations were designed to mitigate the widespread adverse effects to cultural resources caused by the construction of a reservoir, Lake Nighthorse. Although the majority of the significant sites in the ALP project area dated to the early Pueblo period, it should also be noted that important research was done on Late Archaic and Basketmaker II sites (Potter 2008).

Much of the fieldwork at ALP occurred in Ridges
Basin, a perched basin west of the Animas River and just to the west and southwest of the city of Durango, between 2002-2005. The project research filled in important details regarding the early Pueblo occupation of the Eastern Mesa Verde subregion. Although earlier excavations had occurred within the Durango district (figure 5), there had been far less research on the late Basketmaker-early Pueblo periods than in the central portion of the Mesa Verde region. The size of the undertaking allowed archaeologists to document an early Pueblo period landscape with a project comparable in scope to the DAP but with the wisdom gained through 25 more years of research. The ALP investigations were located roughly $60 \mathrm{~km}$ southeast of the DAP project area, which is now inundated by McPhee Reservoir.

Sixteen ALP volumes of site reports, special studies, and syntheses were published between 2006-2010, and the key investigators worked to disseminate their most notable findings in multiple professional journal articles and book chapters. I concentrate here on only a sampling of those professional articles and project volumes. There are many additions that could be made to this summary: among them is a full listing of the ALP volumes and their contents, as well as the other key publications.

The ALP project research design built upon the research questions of the 1999 context but also incorporated new theoretical perspectives that emphasized the importance of human agency and identity in understanding the structure of past human societies. Special studies and the allocation and coordination of research resources were considerably more sophisticated than those of 1525 years earlier at the DAP. In part this was due to the advent of mobile phones, laptop computers, and the creation of the internet, which facilitated the rapid exchange of information and coordination of research efforts. The tightly focused research design of the ALP was a testament to the blossoming of cultural resource management (CRM) as a real force in large-scale archaeological research projects. SWCA was the main archaeological contractor, and the Ute Mountain Ute Tribe, in conjunction with the Bureau of Reclamation, administered the archaeological contract, given that the water to be impounded was part of the settlement of water rights with the two resident Ute tribes in Colorado. 


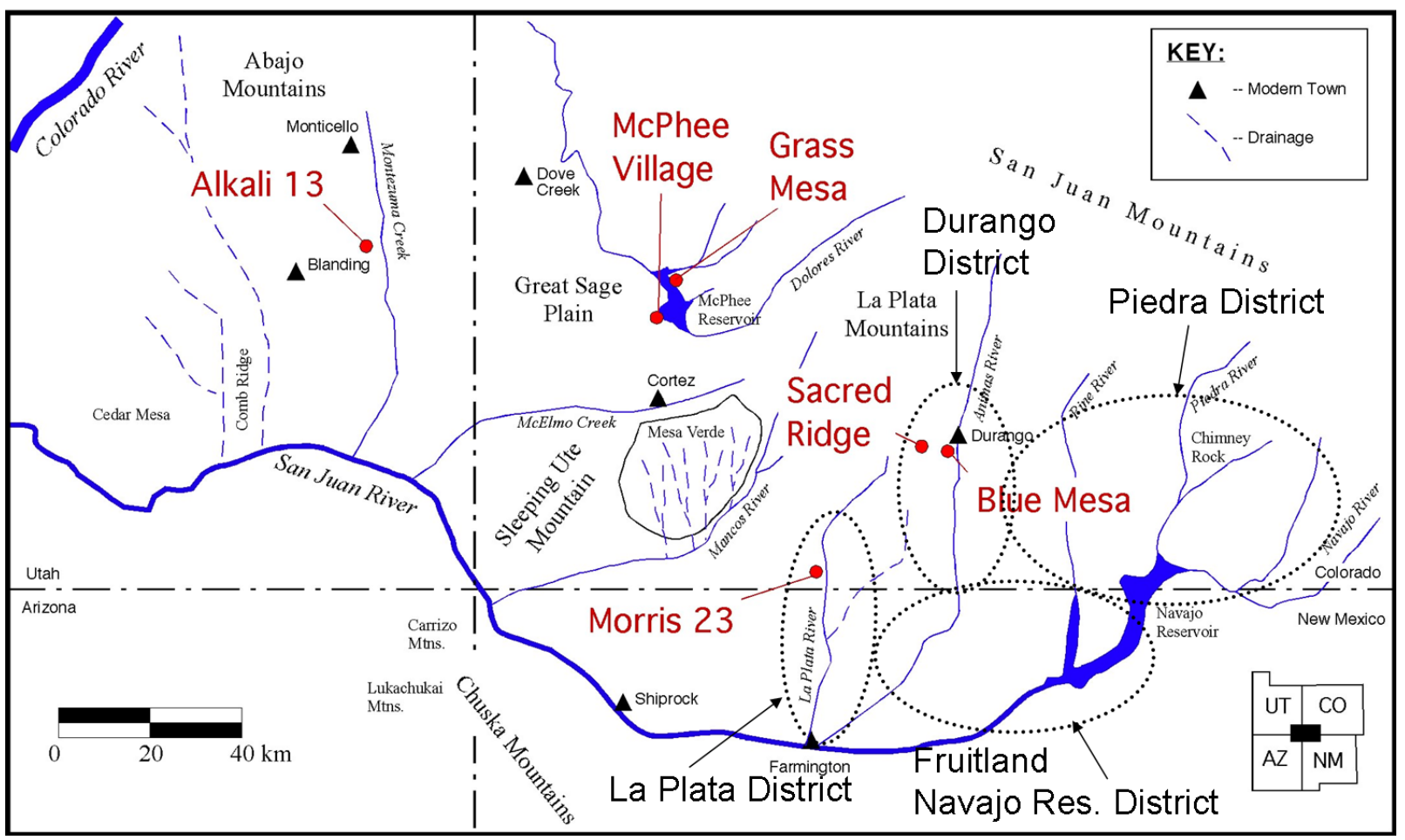

Figure 5. The Durango District and key sites investigated by the Animas-La Plata Project (Sacred Ridge and Blue Mesa) in relation to the greater Mesa Verde region. Figure courtesy of James Potter.

The Animas-La Plata Project shared certain basic research objectives with almost all major archaeological projects of the last 50 years: building a good cultural chronology, reconstructing paleoenvironmental conditions during pertinent research periods, and getting a representative sample of the most significant sites within the research area. In addition to these fundamental research objectives, the ALP investigations highlighted specific topics that focused on the role of houses and households, settlement size and organization, and economic networks as a means to understand the changes and events that occurred in the early Pueblo period. How did these communities come into being? Were these local inhabitants coalescing into more tightly packed communities, or were they immigrants from outside the region? Could the material remains of ritual events or displays of social power be detected, and if so, how did they differentiate individual households or particular communities? These and many other questions about identity and power pushed the ALP investigators to make new discoveries that challenged some of the conclusions derived from the DAP research.
Human health, violence, and burial practices were also central elements of the research design. Many human remains were recovered in the ALP excavations so as to avoid their destruction by dam construction activities and to allow for later reburial. In addition, population movement-both in and out of the research area-was in the research mix for ALP, given the relatively short, but intense, early Pueblo occupation in the Durango area and lack of later Pueblo occupations.

Good chronometric data were difficult to come by, despite considerable investment in obtaining and analyzing numerous dendrochronological, radiocarbon, and archaeomagnetic samples. This made it challenging to make a definitive statement on the occupation span of the main excavated sites at ALP, with a few exceptions (Potter 2010:113121). However, when the chronometric data are combined with the relative dating results of ceramic frequency data, it is evident that the majority of the sampled late Basketmaker-early Pueblo sites dated between A.D. 725 and 825. The occupations of the larger village sites of Sacred Ridge (Chuipka 2009a) and Blue Mesa (Chiupka and Potter 2007) are more 
precisely placed at A.D. $760-810$ and A.D. $775-820$, respectively.

The ALP investigations offered only a very general picture of what people ate and how they made their living. The inhabitants clearly were farmers, and as was the case with the Basketmaker III sites discussed in the previous section, the ALP habitations were located close to alluvial fans or small washes that offered excellent soils, ready runoff, and relatively stable settings for gardens. Experimental garden plots placed within likely agricultural settings and planted with indigenous flint corn varieties similar to the prehistoric corn recovered from nearby dry shelters demonstrated that the available agricultural lands were quite sufficient to produce enough corn to meet the annual needs of the population, even at its estimated maximum (Bellorado 2009). Yet, the storage facilities for maize at some sites were more akin to the small shallow pit rooms typical of the late Basketmaker II period than the well-built and relatively secure masonry storerooms of the early Pueblo period. It may be that households and communities differed in their investment in stored corn surpluses as a hedge against difficult years. If so, households without adequate storage would have needed to fall back on wild resources or to have had exchange relationships that would have allowed them to trade other goods or services for stored foodstuffs such as corn.

Artiodactyls (i.e., deer and elk) and jackrabbits dominated the faunal remains, but a surprising amount of turkey bone was also present (Potter 2012). Turkey typically was not a critical resource until three centuries later when other game resources were increasingly scarce and domesticated turkey was used to supplement meat protein in the diet. This relatively high proportion of turkey suggests that wild game such as artiodactyls may have already been increasingly difficult to procure as the population aggregated into village settings in the Eastern Mesa Verde subregion.

The overall impression from the ALP household analyses was of single, extended family groups centered on pithouse residences, even in early village settings. Unlike the early Pueblo villages at Dolores or Alkali Ridge, with their massive room blocks and associated pit structures, the settlements at ALP ranged from the pithouse village at Sacred Ridge (figure 6) to the concentration of hamlet- sized room blocks and pit structures at Blue Mesa (Chuipka and Potter 2007). There was evidence of household economic specialization and possible interdependence, with some households having many more hunting and meat-processing tools and others having more facilities and tools for storing, processing, and cooking agricultural foodstuffs such as maize. Large houses within communities were significantly more likely to have ritual materials, post-abandonment animal burials, and burning associated with them than were small and mediumsized pithouses. Surface structures were typically small and appeared to have primarily functioned as storage chambers or rooms for specialized tasks such as maize grinding or tool production. Surface room habitations were present but surprisingly rare or of ephemeral construction at most sites.

Consequently, estimating the number of pithouses proved to be the best means of estimating ALP household numbers and overall population, and a momentary peak population estimate of about 600 was calculated for the main occupation span in the area in and around Ridges Basin and Blue Mesa. One of the main challenges for estimating population for the early Pueblo period related to finding the locus of the household: Is it the surface suite of connected storage and living rooms found in mid-to-late ninth-century villages, or is it the pithouse? A review of the literature favors pithouses as household loci for much of the period and for smaller sites (Lightfoot et al. 2014); but for some villages-especially those that have been singled out as possible early great houses (Wilshusen 2017) - the household locus may be in flux, with households increasingly packed into room suites. The agricultural revolution is clearly a period of great variation and experimentation.

Five different settlement clusters were investigated in the ALP work, with two representing clusters of hamlets that were within clear sight of one another and two others that were somewhat more tightly clustered and potentially interpretable as villages. One other, the Eastern Ridges Basin cluster (Yoder and Potter 2007), was a clear settlement cluster but not quite as tightly clustered as most early villages (figure 7). The North-Central Basin (Potter and Yoder 2008a) and Western Basin settlement clusters (Potter and Yoder 2008b) each had a momentary population of approximately 


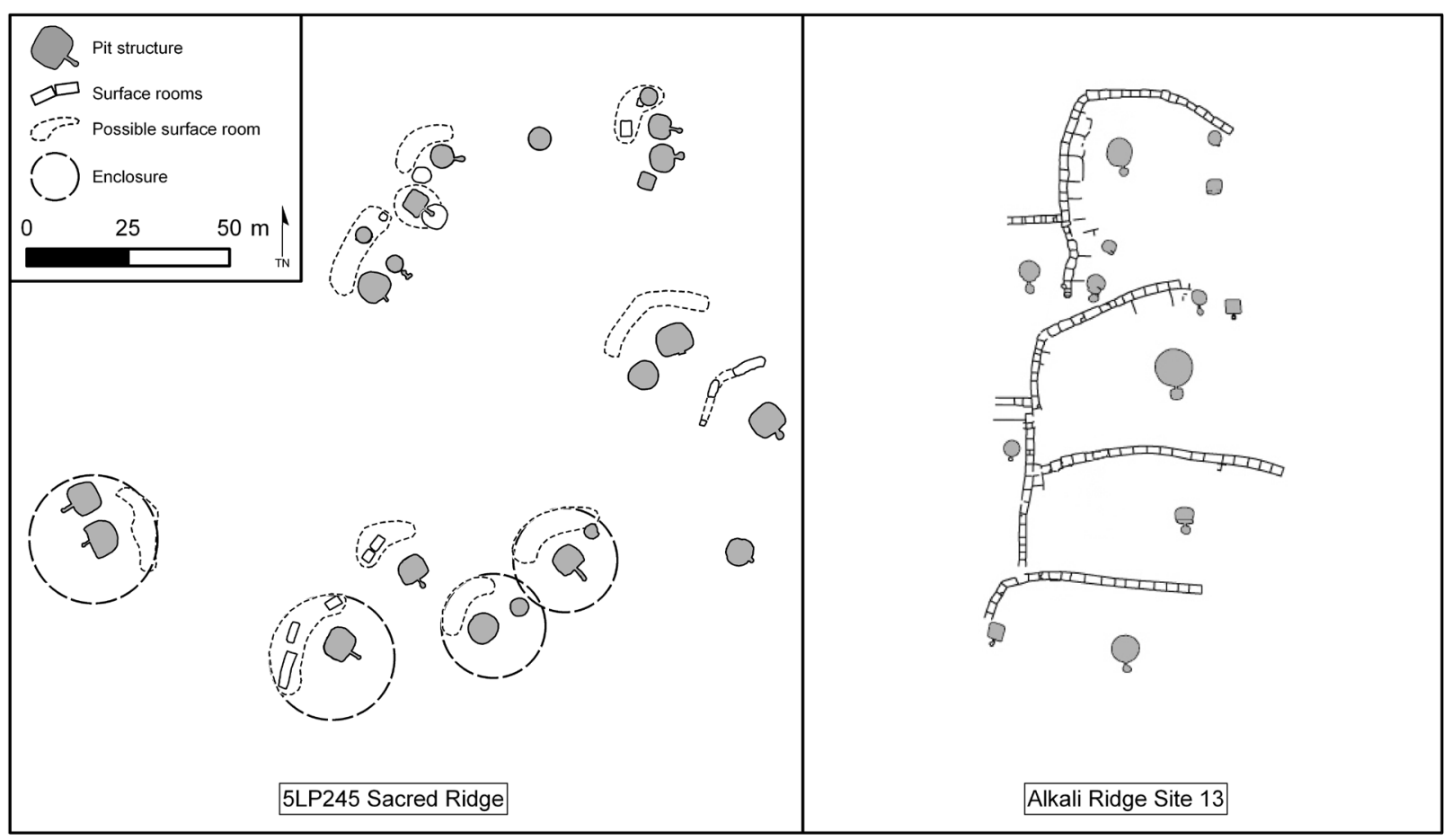

Figure 6. Comparison of the Sacred Ridge pithouse village with the archetypical pueblo village Alkali Ridge Site 13 documented by Brew (1946). The sites had contemporaneous occupations. Although the Sacred Ridge map shows areas of possible surface rooms, it is clear that the rooms, if they ever existed, were far more ephemeral than the room blocks typical of other early Pueblo villages. Figure courtesy of James Potter.

6 to 10 (or more) households spread across the landscape, which may represent latecomers to the area. Some of the settlement clusters appear to have been occupied for a short time-but intensively so-while others had multiple generations of occupation.

Sacred Ridge Village was one of the largest and best organized of the settlements in Ridges Basin (Chuipka 2009a); it was probably the main community center for the basin. Compared to the others, the village had more conspicuous architecture (a possible tower and five over-sized pit structures), and the inhabitants had access to more large game than other settlements (Potter 2009) and greater access to exotic goods, ritual items, and well-made, potentially ritually significant red ware vessels (Allison 2008). Blue Mesa village (Chuipka and Potter 2007), which was roughly equal in population to the Ridges Basin community, was a likely counterpart, but less can be said of it because only a small sample of the village was investigated.

The most striking finding in comparison to Dolores was the tremendous variability among contemporaneous households in neighboring settlement clusters. An examination of pithouse architecture, extramural features, occupation spans, burial patterns, and abandonment modes showed notable variation between settlements (Chuipka 2009b; Potter 2010:209-226; Potter and Chuipka 2007; Potter and Perry 2011). The Eastern cluster was biologically and culturally distinct from the other communities. Its architectural similarities, rich female burials, distinct abandonment rituals, and tightly organized community suggest a discrete population group within the greater Ridges Basin locale. Sacred Ridge similarly appears to have been a distinct group that was quite overt in signaling its cultural differences and prominence. It had rich male burials (opposite the rich female burials in the Eastern cluster), a distinctive village location and design, and several obvious, yet likely controlledaccess, elements of civic-ceremonial architecture (e.g., an early example of a tower).

The ALP excavations also revealed an unusual level of human violence. Numerous remains were found on the floors and in the fills of two of Sacred 
Ridges' pit structures, with the possibility of related fragments of bone in a third (Potter and Yoder 2008c). A minimum of 35 individuals had been killed and then systematically destroyed, resulting in almost 15,000 bone fragments. This assemblage of bone was extensively studied before reburial, and the analysts concluded that the violence likely represented the destruction of a biologically related group of people. Almost all evidence of individual human identity (i.e., facial features, whole bones, and so forth) had been crushed, burned, and destroyed. The overall act is similar to accounts of the destruction of human beings accused of witchcraft (Walker 2008), a widespread phenomenon in many cultures. In the final analysis, however, Potter and Chuipka (2010) concluded that a singular incident of extreme ethnic conflict (Komar 2008) was a better explanation, given the large number of potentially related individuals and wide range of ages (infant to mature adult). The episode occurred near or at the very end of the occupation of the site, and close to the time of the abandonment of all settlements in the Durango area. This discovery, along with other evidence, suggests that the creation, maintenance, and destruction of these early villages - in this area of recent immigrants-were intimately bound up with the aggregation of individuals seeking to affirm and signal distinct identities.

\section{The Strengths and Weaknesses of Big Projects}

Big projects such as ALP or the DAP are once-in-alifetime events in an archaeologist's career. AnimasLa Plata advanced our appreciation of the role of the eastern third of the Mesa Verde region in the overall history of this area in a way that no small project ever could. It confirmed and expanded previous proposals of the cultural diversity evident in the early Pueblo period, and it tested the veracity of many key elements of the Dolores research. While the ALP analyses added considerable nuance to the DAP findings, in many ways its conclusions reaffirmed the fundamental understandings of the early Pueblo period as it was summarized in the 1999 context. If anything, ALP illustrates how archaeology as a practice has matured and changed since the time of the Dolores Project.

The DAP occurred relatively early in the development of modern cultural resource management. It was a unique project in its immense size and scale, its engagement of university researchers, and its essential innovations in the late 1970s, such as its extensive use of archaeological computer data forms and multidisciplinary teams in field recording. The hundreds of archaeologists, numerous graduate student assistants, and future graduate students who worked at Dolores ensured

Figure 7. Aerial
overview of the
Eastern Cluster in
Ridges Basin, one
of five Early Pueblo
settlement clusters
identified by the ALP
investigations. The
sites in this community
cluster were occupied
between the late
eighth and early ninth
centuries and were
contemporaneous with
one another. Image
courtesy of James
Potter.

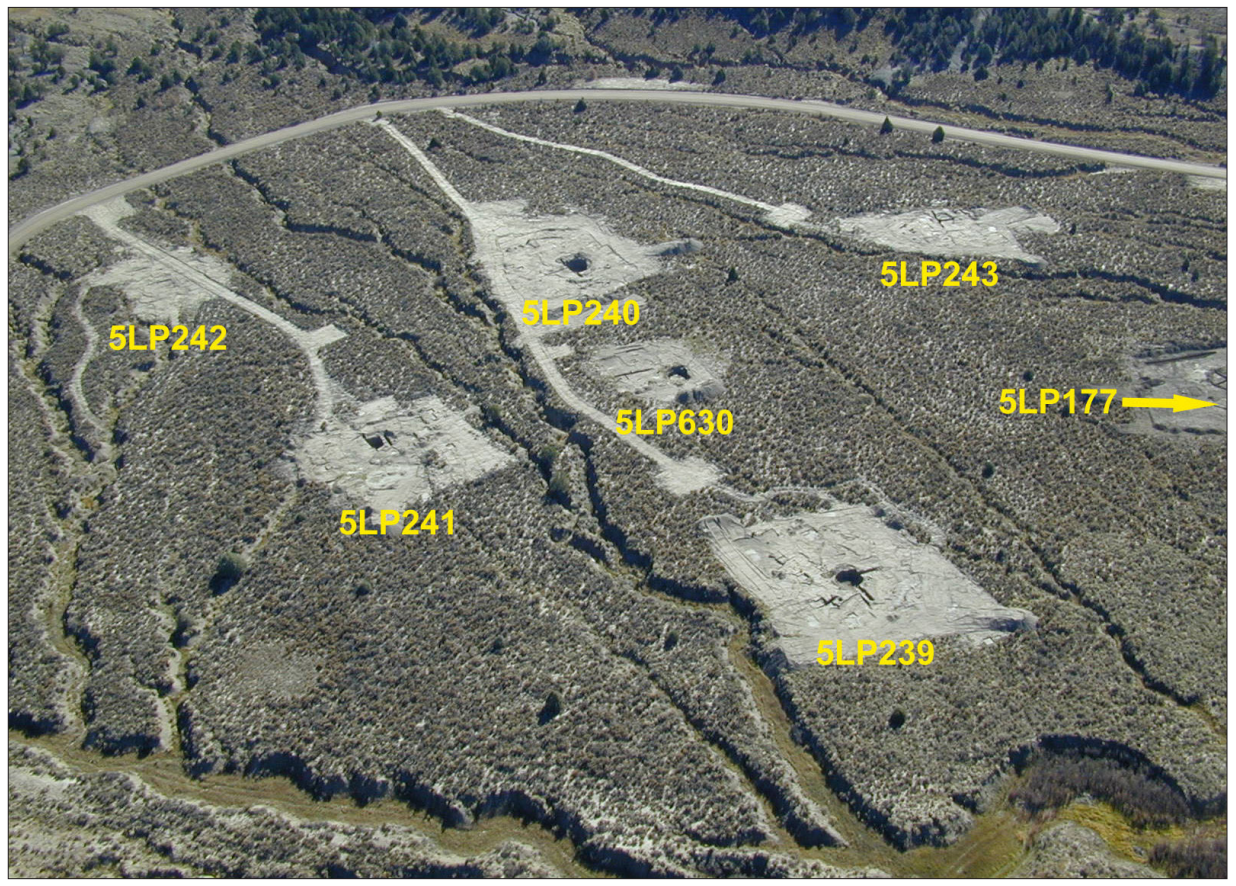


that the research would continue to be used in a way that is difficult to conceive of today.

Over the last three decades there has been a fundamental split between academic, government, and nonprofit/for-profit CRM archaeological practice. Whereas universities primarily did most of the archaeological salvage work until the late 1970s, private CRM firms increasingly fulfilled federally mandated archaeological needs thereafter. In the years after the DAP each different partythe academy, the government, nonprofit research groups, and for-profit CRM firms-took on different archaeological responsibilities. The Bureau of Land Management (the federal government) became the main curator of artifacts at the Anasazi Heritage Center; the alumni of the DAP formed many of the private contracting firms that took on the CRM mitigation work; and nonprofit groups such as Crow Canyon Archaeological Center became the key centers for archaeological innovation and education. The universities that previously had been the primary contractors for archaeological investigations turned their focus to more theoretical research such as the Village Ecodynamics Project (Washington State University).

As Mitchell (2006) demonstrated for the much earlier government contract work in the 1950s and 1960s on the Missouri Basin Project, governmentsponsored archaeology projects often depend on researchers and students from the academy to test the original findings of a project and to utilize the data in future research and theory generation. Certainly, the professors and students who were a part of the DAP-such as Ahlstrom, Blinman, Breternitz, Fetterman, Kohler, Kuckelman, Lightfoot, Lipe, Schlanger, Stodder, Varien, and Wilshusen-expanded on the Dolores research and pushed it out to a wider audience. In the current day, how do we ensure that the ALP digital dataset is utilized and expanded upon in the same way that the DAP datasets are still being used? Increasingly, our challenge is to "mine" the sheer quantity of archaeological observations produced each year (Schlanger et al. 2015). How do we sift through all the site forms and dots on the maps to do better archaeology, plan for the future, and support great research if the universities are not necessarily as intimately engaged in CRM as they once were? How do we monitor the erosion at McPhee Reservoir and
Lake Nighthorse to see if additional research should be done on sites being affected by wave action and the raising and lowering of water levels? The key question is whether it is possible to rejoin the academy, government entities, and nonprofits, as well as CRM firms in a common bond of research and preservation, or whether there are other alternatives to achieve the same result.

\section{Resources for Future Research: Anasazi Heritage Center, Canyons of the Ancients National Monument, and Chimney Rock National Monument}

The Anasazi Heritage Center (AHC) was another outcome of the DAP: it was built to curate the artifacts and records of the archaeological work done to mitigate the effects of the construction of the reservoir and associated irrigation canals and laterals. The center's original purpose was to preserve these materials and records for future research and educate the public about the deep ancestry of the Native peoples of the region and the area's archaeology and history. The AHC was already well established at the time of the publication of the 1999 context, but as the main curation facility in the Four Corners region, it has played an increasingly important role as a resource for understanding, clarifying, and at times challenging the significance of past research. As researchers return to old collections to retest prior assertions, test new analytical techniques, or gain insights for research proposals, critical new findings have emerged. Every project and many of the publications discussed in this review cite the use of AHC collections in their research. Having the DAP ceramic, lithic, perishable, and faunal collections readily available as a resource significantly bolstered the work at ALP and the Basketmaker Communities Project; in addition, significant new collections and research reports housed at the AHC from the work being done by Crow Canyon Archaeological Center, local CRM firms, and the BLM have made this one of the most important curation facilities in the American Southwest.

With the creation of the Canyons of the Ancients National Monument (CANM) by Executive Proclamation in 2000, the Heritage Center building also became the office headquarters for this 
immense new monument. The CANM encompasses approximately 70,000 hectares (170,000 acres) of BLM lands that are managed for multiple uses but with a focus on long-term landscape management to safeguard natural and cultural resources. The fact that this landscape has one of the largest and densest concentrations of ancient Pueblo sites in the Southwest, in particular the large late Pueblo villages that make this region famous, was central to its creation. But the monument also protects a wide range of late Basketmaker and early Pueblo sites, and it may be one of the most important preserves left in the region for early Pueblo landscapes. It deserves far more research attention than it has so far received. Despite a considerable amount of CRM and management work on the monument, published research and context literature specific to these monument lands are restricted to recent work by Crow Canyon and Washington State University (see the Village Ecodynamics Project below) focused on later Pueblo periods and a context for the recent history of this landscape (Horn 2004).

The creation of a national monument offers an effective means to conserve resources, but it also oftentimes provides a reason to reexamine an area that has been ignored by researchers. As a case in point, the archaeological survey and testing work done in planning for the new Chimney Rock National Monument near current-day Pagosa Springs offered surprising insights into the early Pueblo sites of this area (Chuipka et al. 2010). It demonstrated how much more we have to learn about the early Pueblo occupation at the far eastern edge of the Mesa Verde region. Although Roberts $(1929,1930)$ had excavated several important early Pueblo sites just below the well-known Chacoan great house at the center of the new monument, he was such an inexperienced excavator at that time, and the early Pueblo period was so poorly understood, that these early reports are difficult to use in current research. The lesson from Chuipka's recent survey and testing work, and other recent surveys (e.g., Hovezak and Sesler 2004), is that many of the previously known sites can be much more precisely and accurately dated. The occupations of many of the sites in this area fall within the ranges of A.D. $850-900$ or A.D. $1000-1175$. In particular, there are fortress-like pithouse village sites that date to A.D. $880-910$ that likely could teach us a great deal about the movement of people out of the Central Mesa Verde subregion in the late ninth century. As with the CANM, this new monument and the adjacent US Forest Service lands have important cultural resources that need to be incorporated into future regional research and preservation planning.

\section{The Big Picture: The Village Ecodynamics Project}

The Village Ecodynamics Project (VEP I and II) is an NSF-funded research project that has a multidisciplinary team of archaeologists, geographers, computer scientists, and economists working to understand and explain important problems critical to our understanding the creation of the late Pueblo villages and the subsequent abandonment of these villages and out-migration to the current territories of the modern pueblos. The work over the last 16 years (ca. 2002-present) has depended heavily on computer datasets and agentbased modeling to understand household decisionmaking, the economic costs and benefits of different subsistence strategies over time, and the influence of environmental constraints and resource depletion within two large study areas, one in southwestern Colorado (figure 8) and the other in the northern Rio Grande region of New Mexico. The VEP also has contributed to field research by assisting in the funding of important new surveys, as well as multi-year investigations such as the Basketmaker Communities Project.

In the second phase of the project (VEP II), the northern section of the study area was increased to $4,569 \mathrm{~km}^{2}$ and had a dataset of approximately 18,000 sites, with hundreds of these sites being well-dated by dendrochronology. A significant amount of new archaeological field survey, along with estimates of agricultural productivity and better spatial and chronometric data, that underpin the VEP II research have contributed to increased precision in the population estimates for the area from A.D. 600-1300 and a better understanding of the role of environmental change and constraints in population movement (Ortman et al. 2007; Schwindt et al. 2016; Varien et al. 2007). From the beginning, the project's goals have been centered on fundamental questions about early small-scale agrarian societies-that is, on matters important 


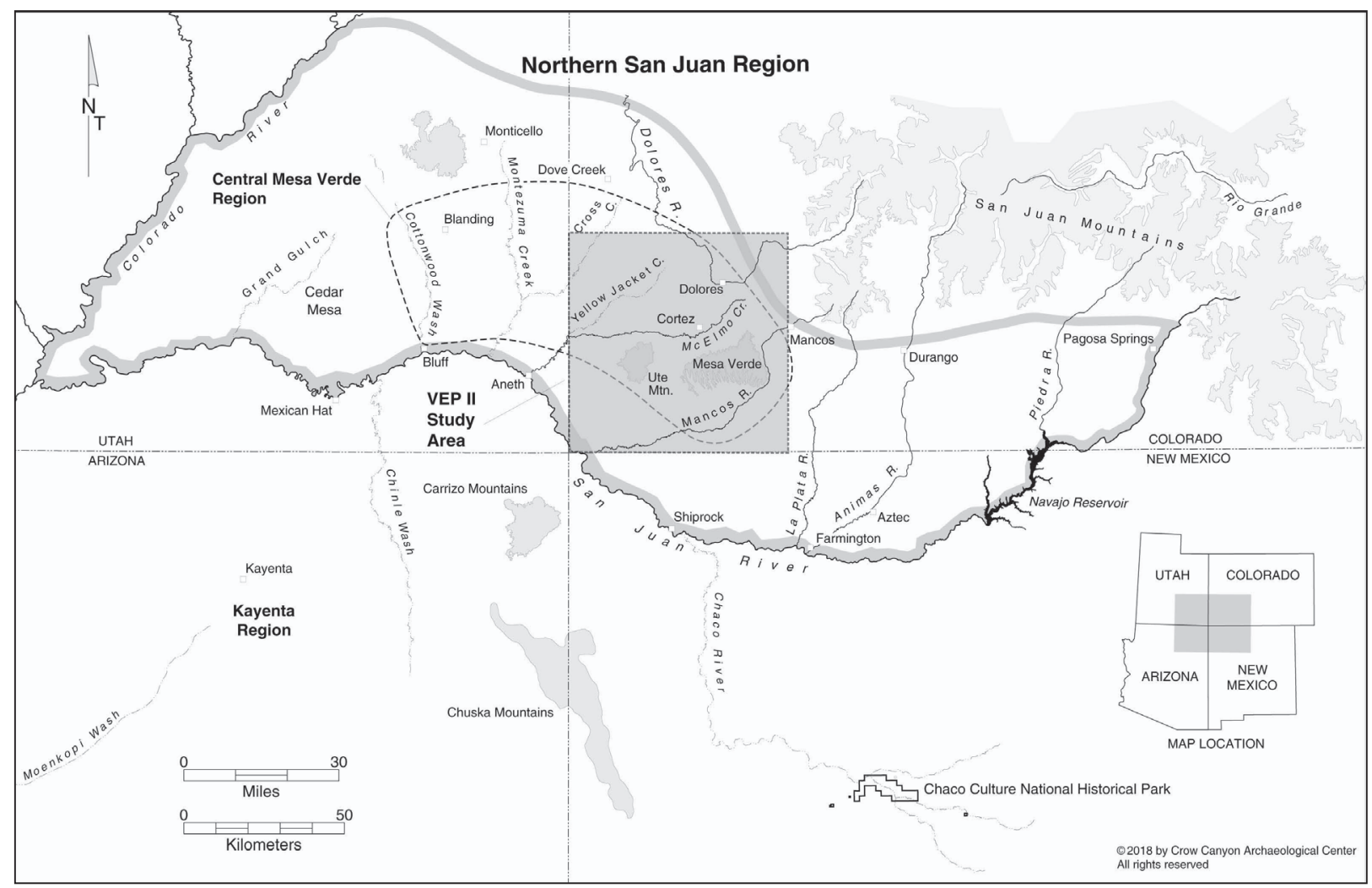

Figure 8. The northern study area of the Village Ecodynamics Project II in relation to the Central Mesa Verde during the Pueblo III period. The Central Mesa Verde subregion during Pueblo I is defined as a significantly smaller area (see Figure 10). Reproduced by permission from the Crow Canyon Archaeological Center.

in the late Basketmaker-early Pueblo periodsuch as the relationship between population size and violence, aggregation and the emergence of socioeconomic inequality, and the rate of change in social institutions (Kohler and Reed 2011; Kohler and Varien 2010; Ortman et al. 2016).

Although the research project initially focused on material constraints and sought to produce better demographic estimates and ecological reconstructions, especially for the later Pueblo periods, researchers have increasingly ventured into investigating issues such as the evolution of leadership and what makes leaders successful or not through conducting agent-based computer simulations (Kohler et al. 2012) of different social strategies. For example, if leaders monitor a group and punish "defectors" or "moochers" in a game about goods shared in common, does that increase the likelihood that group members will achieve a favorable outcome in the simulation? In certain circumstances, it does appear in simulations that households succeed more readily with a leader, who in return receives a share of the group's increased productivity, in comparison to households working in a leaderless group. Some of the simulation outcomes match reasonably well the data known for the early Pueblo period in the Mesa Verde region, and through time, it appears that models incorporating coercion, inter-group competition, or both-and one in which tiered hierarchies of leadership can emerge-would increase the success rate of a group (Kohler et al. 2012).

This project has demonstrated once again the power of combining the resources of a university research project (Washington State University) with the data of a State Historic Preservation Office (SHPO) (Colorado) and federal agencies (BLM and NPS primarily) to create a powerful research tool. Yet, the filtered research data are largely proprietary to the university and its researchers. (For more information, see http://village.anth.wsu. edu.) How do we expand the use of these data and 
similar tools to discern where our best examples of early Pueblo settlements and landscapes might still be preserved, and to implement priority plans to manage, and possibly even acquire, particular sites and landscapes? A small-scale version of how research and preservation can interweave with one another played out when a master's thesis project (Coffey 2007) ultimately resulted in the acquisition of an important late ninth-century village by the Archaeological Conservancy (2008) in an area where preservation is critically needed.

An additional lesson from the Village Ecodynamics Project is that much of the SHPO survey data is mediocre in its data quality, durability, and utility for a great deal of research and planning. As a profession, we have not been sufficiently vigilant in understanding what we can readily, repeatedly, and reliably observe about archaeological sites such as early Pueblo site types. How do we better train archaeologists and design our recording forms to generate higher quality and more "durable" data. In essence, what are the most basic and readily recognizable elements of a site that we need for future research and preservation planning? And how do we create records that can be useful for evaluation and planning purposes both now and 20 years from now (Heilen and Altschul 2013)? We need to subject our recording methods, our SHPO data, and our licensed archaeologists to greater scrutiny, and test the effectiveness and consistency of our current recording methods and forms (Wilshusen et al. 2016).

Although an essential core of late Basketmakerearly Pueblo research was shaped by the 1950s and 1960s work at Mesa Verde National Park and by later reservoir projects such as DAP and ALP, much of the VEP data was derived from more recent surveys done by Crow Canyon, the BLM, the NPS, and other institutions (figure 9). As we begin to assess what is missing in our understanding of this period, the massive VEP database would be an excellent resource for identifying areas where survey is needed or where targeted resurvey would be desirable to obtain a more complete understanding of early agricultural period landscapes. In addition, the combination of "big data" with site-specific artifact analyses (Ortman et al. 2016) has allowed researchers to harness large amounts of regional information to fine-tune our chronological placement of specific sites. By detecting subtle artifact differences that separate early colonizer Basketmaker III sites dating to A.D. 600-650 from the scion sites that come into being two to three generations later (A.D. 650-725), it is possible to see the patterns in the dispersal of populations across a region that otherwise have defied recognition.

\section{New Concepts and Essential Publications}

\section{The Neolithic Demographic Transition}

A 2006 conference organized by Ofer Bar-Yosef and Jean-Pierre Bocquet-Appel brought together over 20 Neolithic scholars from four continents to examine population growth trends in the Neolithic. Bocquet-Appel maintained that the increasing sedentism and carrying capacity of early agricultural societies would potentially yield a finite period of striking population growth until densitydependent or animal-transferred diseases or other problems derived from the increasing population dampened the growth curve. Bocquet-Appel and Naji (2006) suggested that an initial growth period they termed the Neolithic Demographic Transition (NDT) might last between 500 and 1,500 years, and would occur relatively early in a Neolithic sequence, as farming populations began to dominate local landscapes and push out or coopt local huntinggathering or foraging groups.

The Mesa Verde region was well represented at the 2006 NDT conference and in the volume that resulted (Kohler and Glaude 2008; Wilshusen and Perry 2008). In addition, Kohler and other's 2008 article in American Antiquity incorporated additional data to promote the NDT concept in the Southwest and to a much wider audience in North America more generally. The research from Wilshusen and Perry was specific to the Mesa Verde region, and used a large sample $(n=172)$ of the early Pueblo cemetery data from the ALP research to demonstrate surprisingly high population growth rates, even if we took into account a reasonable rate of growth from in-migration. Whereas populationdoubling rates had previously been thought to be on the order of hundreds of years, these cemetery data yielded an estimate that the local population was doubling approximately every 55 years.

The American Antiquity article drew upon 


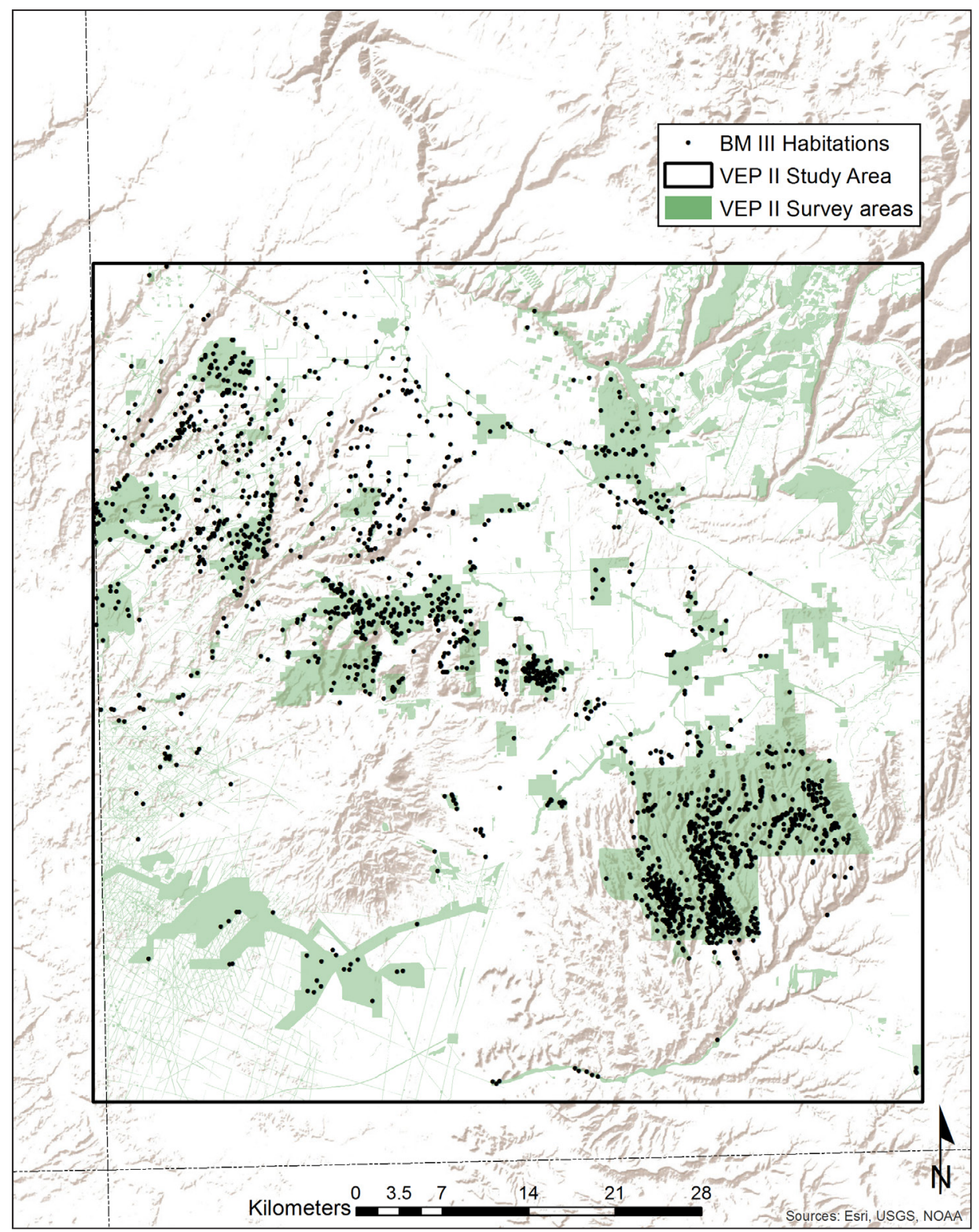

Figure 9. Basketmaker III habitation sites in the VEP II northern study area. Map produced by Scott Ortman.

mortuary data from across the Southwest dating from 1250 B.C. to A.D. 1450 and demonstrated that the NDT was slower to take shape in the American Southwest than elsewhere in the world. Kohler and his colleagues suggested that there was potentially much more regional variability in Southwestern growth rates due to distinct resource differences across the area. In common with many Neolithic peoples, these early Pueblo populations experienced very high birth rates, especially between A.D. 500 and 1300. Despite a low life expectancy for any particular individual at birth, the average increased number of children per household led to much faster than expected doubling rates in the population. The overall effect was a long period of greater than expected population growth. Previously, we had paid far too little attention to issues associated with high population growth, such as the colonization of new areas by rapidly growing populations and the competition and conflicts that were likely sparked by mounting resource scarcity in areas of high population density.

The NDT collaborations drew Southwestern researchers and their research into larger discussions of the Neolithic and emphasized the need to stay connected with worldwide research and current 
issues (Kohler and Reese 2015; Kohler et al. 2014; Shennan et al. 2013). The Southwest is so very rich in information and so very active archaeologically that it is far too easy to confine ourselves to regional debates and publications-and fail to recognize that the Southwest offers one of the best examples of a Neolithic sequence in the world.

\section{Crucible of Pueblos}

Partly in reaction to the NDT conference in 2006 and to frame the just completed ALP research, Richard Wilshusen and Jim Potter gathered 23 scholars in 2007 to place late Basketmaker and early Pueblo research into a larger perspective. The discussions were lively and incredibly informative, and they ultimately led to a book that examined the early Pueblo period across the northern Southwest. Crucible of Pueblos: The Early Pueblo Period in the Northern Southwest was published by the Cotsen Institute at UCLA in 2012. The 13-chapter volume consists of an introduction, overviews of six different regions or subregions in the northern Southwest, four chapters on special studies or topics, and two concluding chapters by scholars offering assessments of the research and suggestions for future needs. The area covered in the volume is expansive, with the eastern border marked by the Northern Rio Grande Valley, the south delimited by the Mogollon Rim, the west bordered by the Little Colorado and Colorado rivers, and the north marked by the Mesa Verde region (figure 10).

The volume focused on a temporal span (A.D. 650-950) that included Basketmaker III, Pueblo I, and the early part of Pueblo II. By ignoring the somewhat different boundaries of the traditional Pecos periods for each region or subregion, the authors were able to focus on the patterns of regional change across whole landscapes rather just trying to fit individual sites into the chronological framework specific to any one region or subregion.

Crucible of Pueblos offers a wide-ranging overview of the period, but the chapters most immediately useful for someone working in the Mesa Verde region are the summary chapters on the three Mesa Verde subregions, with the Eastern Mesa Verde covered by key ALP researchers (Potter et al. 2012), the Central subregion synthesized by Wilshusen, Ortman, Diederichs, Glowacki, and
Coffey (2012), and the Western subregion covered by Allison et al. (2012). These chapters bring together comprehensive updates and pay even greater attention to the differences across the Mesa Verde region from the late Basketmaker through the early Pueblo period than was possible in the earlier context chapters (Wilshusen 1999a, 1999b) or in this update. Although the 1999 context still offers a quick and useful overview, the three 2012 chapters are highly recommended to anyone working in or researching the area. The twelve authors who wrote the three chapters brought a depth and breadth of knowledge and experience that no single author could summon. The early Pueblo overviews of the Northern Rio Grande, Chaco Basin, and the Little Colorado drainage advance a far-reaching view of the northern Southwest and should be consulted if greater perspective is needed.

The introduction (Schachner et al. 2012) to the volume may be useful to scholars who want additional background on the early Pueblo period, as it frames the history of research on the period and offers a concise summary of key contemporary research issues. The volume organizers knew that for special studies a full range of issues in contemporary research could not be addressed, given that there are whole volumes devoted to just the special studies for medium to large archaeological projects. The wide range of analytical topics, sophistication of the techniques available, and sheer volume of data is astonishing when compared to archaeological projects of only a generation ago. Accordingly, the authors tried to assemble a cross section of studies that demonstrated how certain specialties or topics have turned our understanding of the early Pueblo period upside down in the last decade. Although not comprehensive, the special studies chapters discussed current issues such as how gender roles were redefined in the period (Wilshusen and Perry 2012), how social power appears to have been expressed through cuisine (Potter 2012), how patterns of social identity can be traced through time in perishable items (Webster 2012), and how to use multiple lines of evidence from sources we often ignore (rock art, historical linguistics, and architectural variables) to make a more complete argument about changes in Pueblo leadership from A.D. 650 to after A.D. 950 (Wilshusen, Ortman, and Phillips 2012). 


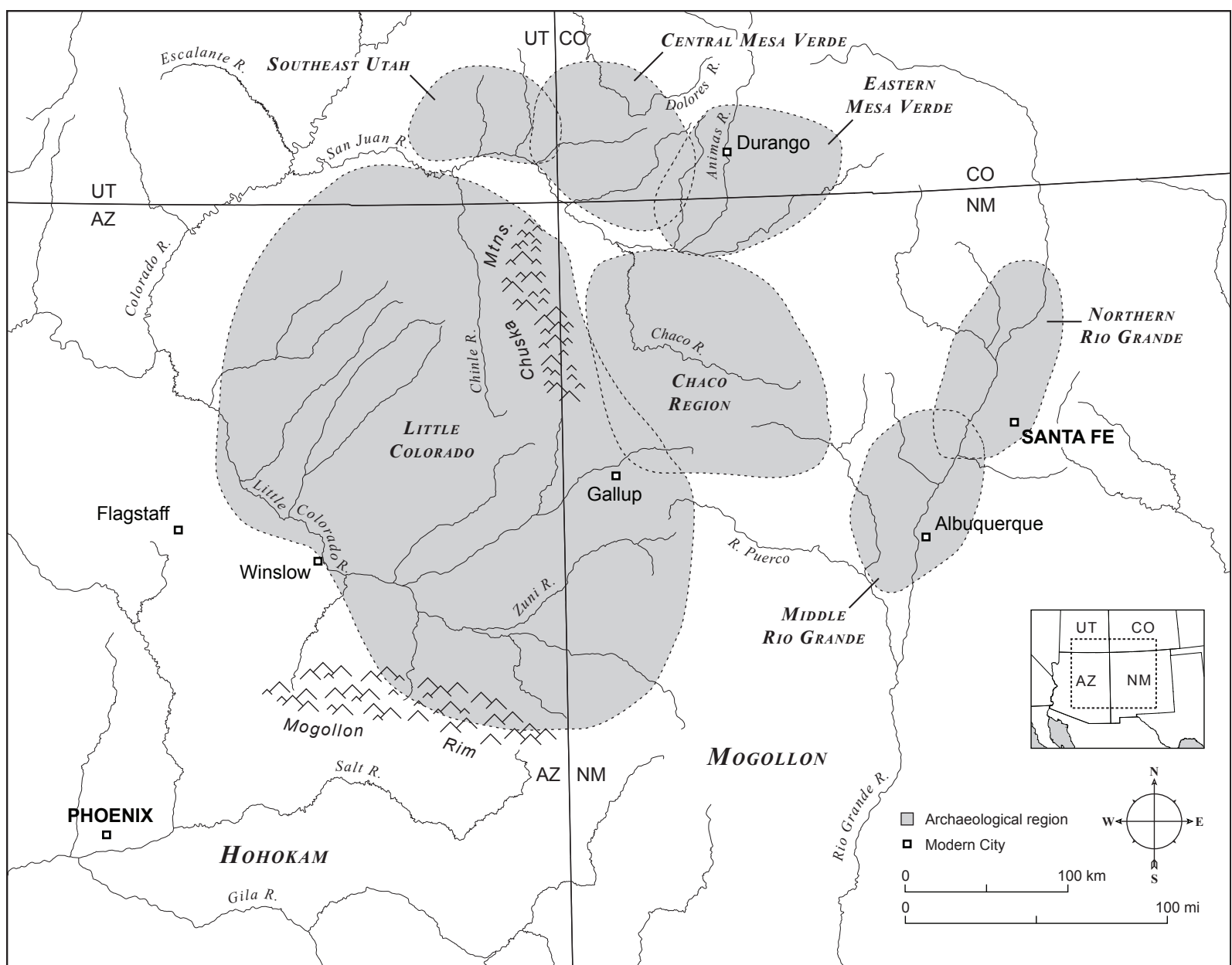

Figure 10. Early Pueblo period regions and Mesa Verde subregions of the northern Southwest (adapted from Schachner et al. [2012:Figure 1.1]). Map produced by Phil Geib.

The two concluding chapters by Lekson and Kantner offer views of what is worthy in the book, and, more important, what early Pueblo research should turn to in the future. Kantner's (2012) chapter is especially good at critiquing where current interpretations and data fall short. Anyone researching the period should seek the counsel of this chapter. Although the focus of the book was the creation of some of the earliest pueblos, the authors did not offer a unified explanation of why people chose, in almost equal proportions, to either gather together in villages of hundreds of people or live in much smaller dispersed hamlets of two to four households. Kantner remedies this somewhat in his summary by discussing the potential benefits of aggregation and noting its limited costs. Some of his suggestions refine ideas presented in his earlier publication on leadership (Kantner 2010). He also pushes researchers to better understand why there are a wide variety of village plans evident in the period. And although he considers environmental issues, the costs of village life, and the threat of violence, Kantner always returns to the issue of leadership as central to any explanation of early village formation. In a sense, he foreshadows the work of Kohler and others (2012) in suggesting that effective villages leadership helps to generate public goods through rituals of sharing, institutions and leadership for common defense, and an overall increased flow of information and cooperation throughout a community. He ends with a short discussion of the obvious need for centralized and enduring leadership in villages, whether we look at modern ethnographic accounts or archaeological case studies, and the failure of most early villages to last more than two or three generations. The 
failure to create sustainable leadership in these early villages must have offered lessons for the nascent leaders of the great house system of community organization that followed in the tenth century.

\section{Early Great Houses and the Chaco Synthesis}

The first decade of the twenty-first century brought new appreciation for what made the early Pueblo period a "turning point" in Pueblo prehistory. Among the challenges that had been noted in the 1999 context was our lack of understanding of how to relate the ninth-century population peak and villages in the Mesa Verde region to the tenthand eleventh-century developments in the Chaco Basin. Lekson helped to remedy this situation by bringing together a wide range of scholars to create a synthesis of what had been learned from the Chaco Project of the 1970s and early 1980s. These small working groups convened in a series of meetings between 1999 and 2002, and out of these discussions and from the issues raised for the Mesa Verde region in the 1999 context, a general consensus was reached. Working from similar data but from different perspectives, Windes, Wilshusen, Van Dyke, and others all concluded that some of the earliest examples of great houses were actually embedded in particular ninth-century Mesa Verde villages and were evident as massive $\mathrm{U}$-shaped room blocks and oversized pit structures within these villages of clustered room blocks (Van Dyke 2007; Wilshusen, Hurst, and Chuipka 2012; Wilshusen and Potter 2010; Wilshusen and Van Dyke 2006; Windes 2004, 2007). In a sense, these U-shaped or double-U-shaped room blocks north of the San Juan River provided a blueprint for how to redesign the small unit pueblos at the core of sites such as Pueblo Bonito, Peñasco Blanco, and Una Vida into what would later become the nascent great houses of the tenth century, and thereafter the great houses of Chaco Canyon (figure 11).

Archaeologists have long recognized the architectural monumentality of certain structures excavated by the DAP, such as the imposing great kiva on Grass Mesa (Adler and Wilshusen 1990; Lightfoot 1988), but only recently have they also seen the massive U-shaped masonry room block and over-sized pit structure at McPhee Pueblo as monumental (Windes 2004). This very monumentality might suggest differences in material wealth among certain households, but most researchers who have examined the Dolores data and other early Pueblo village research in this region can point to very few or only subtle differences in material wealth between households. Instead of material wealth, it appears that early Pueblo leaders, especially those living in the massive U-shaped pueblo great houses, amassed power through their sodalities or lineages, or through their own embodied power to control community rituals and religious performances (Wilshusen 2017). Wilshusen, Ortman, and Phillips (2012:208)

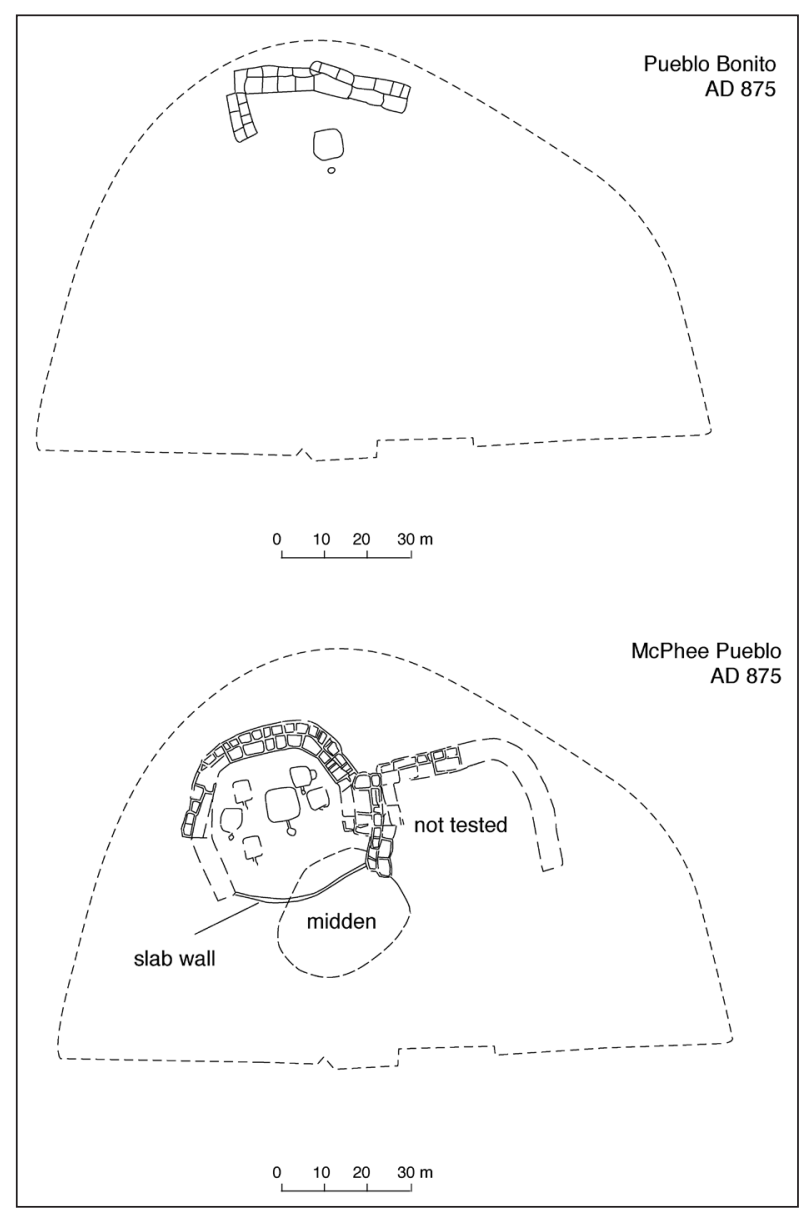

Figure 11. Comparison of the Pueblo Bonito room block at A.D. 875 and the room block at McPhee Pueblo from the same time, with both set against the dashed outline of what the Pueblo Bonito room block will grow to be by A.D. 1115. The large U-shaped village pueblos of the ninth century in the Mesa Verde region appear to have been the earliest "great houses." Figure produced by Phil Geib. 
suggest that " $[\mathrm{t}]$ he significant change brought about by village formation ... was the unification of private and public ritual in a single built environment." These authors and others argue that the transformation of community socioreligious institutions, feasting, the control of ritual knowledge, and securitynot overly conspicuous individual or household wealth differences-was at the heart of the political organization and the power garnered by particular households or individuals in these early villages (Potter 2012; Wilshusen, Hurst, and Chuipka 2012; Wilshusen, Ortman, and Phillips 2012; Wilshusen and Potter 2010).

Clearly, the control and display of material wealth in the tenth- and eleventh-century great houses of Chaco Canyon and the San Juan Basin represent something fundamentally different from what is seen in these early Pueblo villages. Though various researchers (Van Dyke 2007; Ware 2014; Wilshusen 2015, 2017; Wilshusen, Hurst, and Chuipka 2012; Wilshusen and Van Dyke 2006; Windes 2004, 2007, 2015) have argued that the architectural construction, community layout, ritual organization, and large size of particular Dolores village room blocks made them early candidates to be interpreted as "great houses," these researchers also have emphasized the striking cultural and organizational differences between the late ninthcentury Mesa Verde villages north of the San Juan River and the tenth-century great houses south of the river.

McPhee Village appears to have had only one great house (McPhee Pueblo) within the 18 room blocks that made up the settlement (figure 12), and although this great house appears to have played a distinctive role in village rituals and feasting, there is little evidence that the leaders of McPhee Pueblo controlled the daily lives of the inhabitants of the larger village. The "house societies" that have been identified ethnographically (Lévi-Strauss 1982) and archaeologically (Beck 2007) may offer the best examples of how these great house communities operated. In such a society, the blatant use of power is more a sign of weakness than of strength. Whatever power there was in these early villages, it was insufficient to hold them together for more than 30 or 40 years, or no more than two to three generations after the villages were established. In the case of McPhee Village, the community lasted from approximately A.D. 830 to 880 and had a peak population of at least 300 people. Although it must have been impressive-even great for its timewhen the end came McPhee broke apart rather quickly. Close to the time of its abandonment, at least four pairs of male and female adults (perhaps couples) were suffocated and entombed in several of the larger pit structures across the village. In addition, key over-sized pit structures, including the one in McPhee Pueblo, were ritually burned down throughout the village (Wilshusen 1986).

Tenth-century leadership, community organization, and possibly even household economies must have been informed by both the successes and the failures of these early great houses such as McPhee. Using this knowledge, the leaders of the Chaco-era great houses were able to assemble a system that was many times greater in size, conception, and length of occupation than their predecessors in the Mesa Verde region (Heitman 2015; Mills 2015; Wilshusen 2015, 2017; Windes 2015). Yet, the historical ties to Mesa Verde and these earliest of great house are still strikingly evident as the early Chaco system comes into being.

\section{What We Have Learned}

Nearly two decades ago, my treatment of the Basketmaker III period was largely descriptive and focused on describing chronological change and characterizing the archaeological record as best I could based on data from 42 reasonably wellexcavated, tree-ring dated sites, along with a much larger sample of less well-dated late Basketmaker sites (Wilshusen 1999a). Although I had an inkling that immigration, population growth, and cultural identity and diversity would be important research topics, I could not have known how research in the northern Southwest, and especially in the Mesa Verde region, would be transformed as we began to have easy access to the digital tools necessary for amassing and analyzing our data at a regional level. In addition, as the power of the internet and data exchange increased exponentially, we began to engage in a worldwide dialogue about Neolithic change and to recognize how much our own data could contribute to the larger understanding of the changes that occur in early agricultural societies elsewhere. 


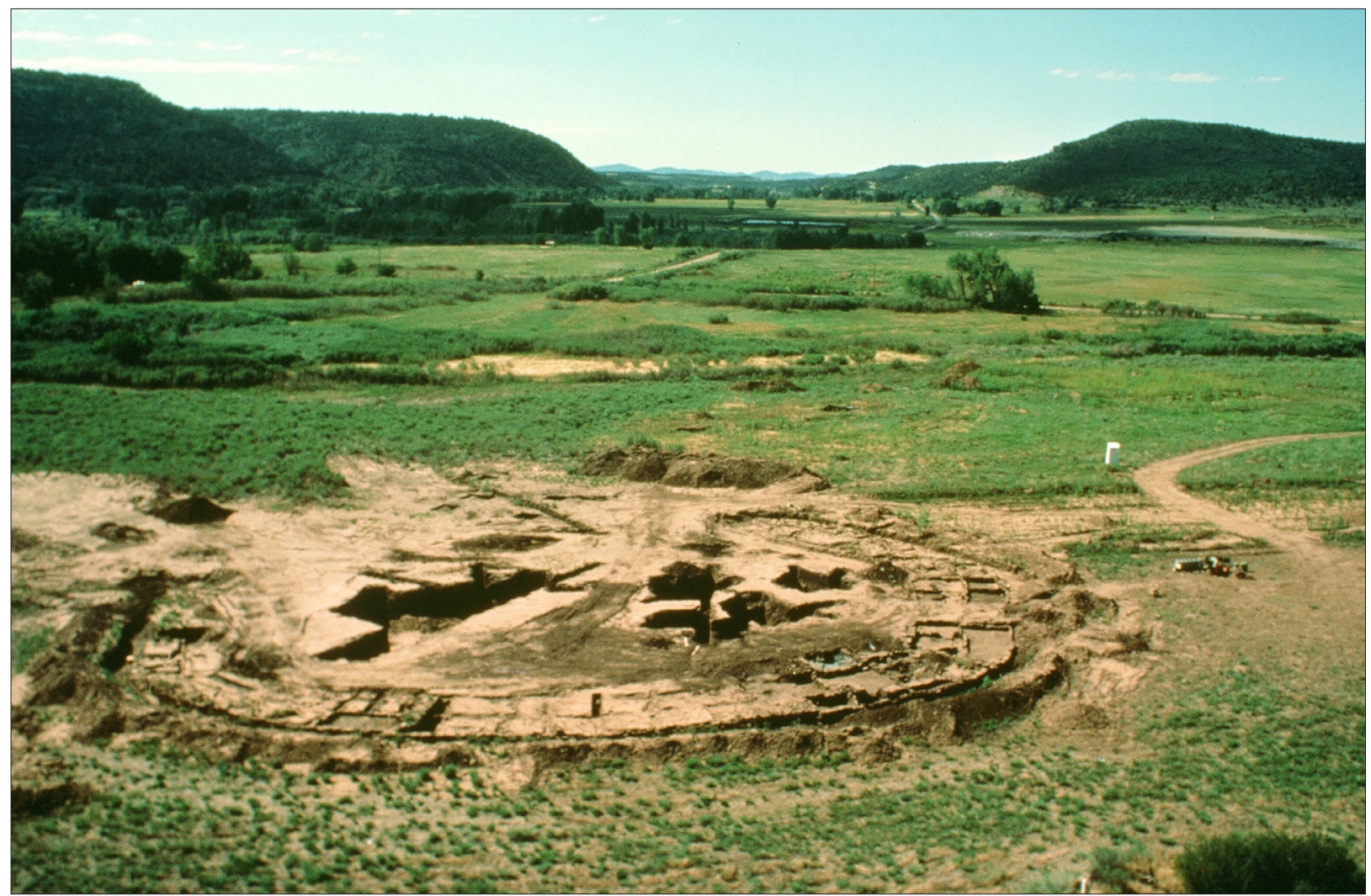

Figure 12. Pueblo de las Golondrinas (Site 5MT5017), a large pueblo in McPhee Village, a village composed of a tight cluster of 18 pueblos. The pueblo room block is outlined by the excavations in the foreground and measures almost exactly $50 \mathrm{~m}$ along the back wall. Pit structure exploratory excavations are evident in front of the room block, towards the center of the photo. Facing south, photo taken in August 1981. Image courtesy of Neal Morris.

Although my views and information on the early Pueblo period in 1999 were far more developed than my understanding of the late Basketmaker period, there is a surprising provincialism when I now reread my explanation of how early pueblos and early villages came into being in the Mesa Verde region. The Pueblo I summary (Wilshusen 1999b) still is useful as a descriptive synthesis, but it contributes only a fraction of what we currently know about this period. Large projects such as the ALP, the VEP and its related Basketmaker Communities Project, and the syntheses of different topics and regions in the Crucible of Pueblos (Wilshusen, Schachner, and Allison 2012) have challenged us to think on a broader scale about our research. The new national monuments at Canyons of the Ancients and Chimney Rock serve to remind us that archaeology is not just about research-it's also very much about planning and preservation. In these last paragraphs, I will suggest what I think are some of the most notable changes in our thinking.

First and foremost, what I described in 1999 as two different Pecos periods, Basketmaker III and Pueblo I, within Mesa Verde history are now seen as a continuum of sweeping changes and a key turning point in the history of the northern Southwest. The widespread, relatively rapid changes in population, community organization, and landscape use essentially turned the early Pueblo world upside down (Schachner et al. 2012). With the widespread adoption of an agricultural lifeway sometime between A.D. 300 and 500, there was a demographic transition that led to a rapid rise in population both from the intrinsically higher population growth rates of early sedentary agricultural societies (Kohler et al. 2008; Wilshusen and Perry 2008) and the immigration of other agriculturalists into the Mesa Verde region (Diederichs 2016; Ortman et al. 2016; 
Wilshusen 2009). As population continued to grow and as competition and conflicts over resources increased (Wilshusen and Potter 2010), more and more dispersed communities experimented with gathering into villages of a hundred or more people (Wilshusen, Ortman, Diederichs, Glowacki, and Coffey 2012). In addition to shared security, villages appear to have offered other public goods such as shared leadership, powerful rituals, the redistribution of scarce commodities in times of need, and communal hunts (Kantner 2012; Kohler and Reed 2011; Kohler et al. 2012).

Although we had previously identified potential ethnic/cultural differences in particular early Pueblo villages (e.g., Wilshusen and Ortman 1999), there has been a wider recognition of how late Basketmaker and early Pueblo immigrants contribute to the rapid growth of these early agricultural communities. These differences are evident across the region, as well as in particular early villages (Potter and Chuipka 2007; Potter and Perry 2011). In addition, we now recognize that early "great houses" were embedded within some of these ninth-century villages (Wilshusen and Van Dyke 2006; Windes 2004) and that these settlement forms and their leadership modes (Wilshusen 2017; Wilshusen, Ortman, and Phillips 2012) appear to have significantly shaped the Chaco great house system that emerged over the next two centuries (Kantner 2012; Windes 2015).

It's clear that the social structure, and possibly the very conception of society, changed within the span of three or four generations. For example, with larger households, more children, and an increasing number of daily tasks ranging from mealing corn to keeping the house supplied with clean water, women must have shouldered ever-more-critical roles in the success of a household. And in turn this intensification of the domestic activities would have necessitated more pottery, better-designed manos and metates, cradleboards for young children, and other domestic tools for daily duties. If I could walk into an early village, I would expect to find a multilingual society in which the roles of men and women, leaders and followers, children and elders were increasingly structured by the demands of living in a large village, a place where households shared common walls and the inhabitants shared in communal tasks and rituals.
As research from this region has been presented more widely in national and international forums, it has become clear that the late Basketmaker to early Pueblo period in the Mesa Verde region offers one of the best case studies in the world for understanding the dramatic transformations wrought by early agriculture. We still need to do good site-specific research, but we also increasingly need to enlarge our research focus to the larger agricultural landscape to address the broader questions about how early agriculture changed people's social and economic behavior. The Neolithic reshaped the whole world, and the Mesa Verde region may be one of the best laboratories for studying early farming cultures.

In a forthcoming contribution to Reviews in Colorado Archaeology, I will suggest that we must expand what we consider the context area to address issues of importance that are not bounded by state lines. In addition, I will argue for increasing the use of the terms "late Basketmaker" and "early Pueblo" in place of the traditional Pecos period terminology for reasons that will be laid out in that article. Finally, I will propose new research themes and heritage management priorities that seek to balance site-specific research with the need for broadly conceived preservation so that significant sites and those landscapes with sufficient integrity can be considered for long-term preservation. We must widen the focus of our research efforts, our mitigation designs, and our preservation planning if we are to make real progress in understanding and protecting the significance of this early agricultural landscape. Having representative elements of this landscape-sites, potential field locations, special use areas, viewsheds-available for future research and future public visitation will offer a chance to glimpse what the world might have looked like at the beginning of the agricultural revolution in the Southwest.

As I close, I must emphasize to the reader that this review-lengthy though it may be-represents only a small, but hopefully significant, sample of the late Basketmaker-early Pueblo research that has occurred in the Mesa Verde region since 1999. This review is not intended to be comprehensive; it is an introduction to some of the literature I have found most useful. Since I wrote some of this literature, I am clearly biased! But, I hope it is at least a sufficient appraisal of what we have done these last decades 
for readers who are already experienced in the area, and a readable introduction for those who need a condensed version of recent research. I encourage readers to use the tools on the ORCA website (http://www.archaeologycolorado.org), such as the User Forum, the Research Links, or one of the other features, to add to what I have offered here, discuss differences of interpretation, call attention to new research that I missed, or point out any errors. Archaeology is a social science, and the way we move forward is to work with one another to learn even more about the deep and wonderful past of a place such as the Southwest.

Acknowledgments. The suggestions of two anonymous reviewers in combination with specific changes recommended by the editor of this journal profoundly improved this review. The generosity of those who permitted the use of previously published figures is deeply appreciated, with special thanks due to Phil Geib and Scott Ortman for adapting figures specifically for this piece. Since the publication of the 1999 context I have had the good fortune to coauthor or co-edit publications cited here with 19 colleagues. They have taught me much of what I have shared in this piece. Christine Weeber's final copyedit of the revised manuscript helped to corral my commas and contain my affection for em dashes.

\section{References Cited}

Adler, Michael A., and Richard H. Wilshusen

1990 Large Scale Integrative Facilities in Tribal Societies:

Cross-cultural and Southwestern U.S Examples. World Archaeology 22:133-145.

Allison, James R.

2008 Exchanging Identities: Early Pueblo I Red Ware Exchange and Identity North of the San Juan River. In The Social Construction of Communities: Agency, Structure, and Identity in the Prehispanic Southwest, edited by Mark

D. Varien and James M. Potter, pp. 41-68. AltaMira Press, Lanham, Maryland.

Allison, James R., Winston B. Hurst, Jonathan D. Till, and Donald C. Irwin

2012 Meanwhile in the West: Early Pueblo Communities in Southeastern Utah. In Crucible of Pueblos: The Early Pueblo Period in the Northern Southwest, edited by Richard H. Wilshusen, Gregson Schachner, and James R. Allison, pp. 35-52. Cotsen Institute of Archaeology Press, University of California, Los Angeles.

Archaeological Conservancy (Anonymous)

2008 Preserving an Unusual Pueblo-Period Village. American Archaeology 12(3):47.

Beck Jr., Robin A.

2007 The Durable House: House Society Models in Archaeology. Center for Archaeological Investigations, Southern Illinois University, Carbondale.
Bellorado, Benjamin A.

2009 A Reconstruction of Prehistoric Subsistence Agriculture in Ridges Basin. In Animas-La Plata Project, Vol. XIII: Special Studies, edited by James M. Potter, pp. 215-233. SWCA Anthropological Paper Number 10. SWCA Environmental Consultants, Phoenix.

2011 Pushing the Limits and Tormenting Corn Seeds: Cultural Adaptations and Climatic Change in the Upper San Juan during the Basketmaker II Period and Beyond. Southwestern Lore 77(2-3):33-48.

Birkedal, Terge G.

1976 Basketmaker III Residence Units: A Study of Prehistoric Social Organization in the Mesa Verde Archaeological District. Unpublished Ph.D. dissertation, Department of Anthropology, University of Colorado, Boulder

Bocquet-Appel, Jean-Pierre, and Stephan Naji

2006 Testing the Hypothesis of a Worldwide Neolithic Demographic Transition. Current Anthropology 47:341365.

Breternitz, David A.

1993 The Dolores Archaeological Program: In Memorium. American Antiquity 58(1):118-125.

Brew, J. O.

1946 Archaeology of Alkali Ridge, Southeastern Utah. Papers of the Peabody Museum of American Archaeology and Ethnology, Harvard University 21. Cambridge.

Charles, Mona C.

2011 Refining the Chronology of the Durango Basketmakers. Southwestern Lore 77(2-3):21-31.

Chenault, Mark L.

2004 Archaeological Investigations at Dead Dog Hamlet (Site 5MT11861): A Basketmaker III Habitation Site. In From Dancing Man to Hummingbird: LongTerm Prehistoric Change in Southwest Colorado, Vol. 2, edited by Mark L. Chenault, Cynthia Manseau, and Todd Kohler, pp. 5.1-5.200. SWCA Environmental Consultants, Broomfield, Colorado.

Chenault, Mark L., Cynthia Manseau, and Todd Kohler (editors)

2004 From Dancing Man to Hummingbird: Long-Term Prehistoric Change in Southwest Colorado, Vols. 1 and 2. SWCA Environmental Consultants, Broomfield, Colorado.

Chenault, Mark L., and Thomas N. Motsinger

2000 Colonization, Warfare, and Regional Competition. In Foundations of Anasazi Culture: The BasketmakerPueblo Transition, edited by Paul F. Reed, pp. 45-65. University of Utah Press, Salt Lake City.

Childe, V. Gordon

1951 Man Makes Himself. New American Library of World Literature, New York.

Chuipka, Jason P.

2009a Animas-La Plata Project, Vol. XII: Ridges Basin Excavations-The Sacred Ridge Site. SWCA Anthropological Research Paper No. 10. SWCA Environmental Consultants, Phoenix.

2009b Exploring Ethnic Diversity and Sociopolitical Strategies of Early Pueblo Villages in the Northern San Juan Region of the American Southwest, A.D. 750-840. In 
Animas-La Plata Project, Vol. XIII: Special Studies, edited by James M. Potter, pp. 43-83. SWCA Anthropological Research Paper No. 10, Vol. XIII. SWCA Environmental Consultants, Phoenix.

Chuipka, Jason P., and James M. Potter

2007 Animas-La Plata Project, Vol. III: Blue Mesa Excavations. SWCA Anthropological Research Paper No. 10. SWCA Environmental Consultants, Phoenix.

Chuipka, Jason, Richard H. Wilshusen, and Jerry Fetterman

2010 The Northern San Juan Basin Settlement and Survey Project, Archuleta and La Plata Counties, Colorado. Report submitted to the San Juan Resource Center, Durango.

Coffey, Grant D.

2007 Reevaluating Regional Migration in the Northern San Juan during the Late Pueblo I Period: A Reconnaissance Survey of the East Dove Creek Area. Kiva 72:55-70.

Coltrain, Joan, Joel Janetski, and Shawn Carlyle

2006 The Stable- and Radio-Isotope Chemistry of Eastern Basketmaker and Pueblo Groups in the Four Corners Region of the American Southwest: Implications for Anasazi Diets, Origins, and Abandonments. In Stories of Maize: Multidisciplinary Approaches to the Prehistory, Biogeography, Domestication, and Evolution of Maize (Zea Mays L.), edited by John Staller, Robert Tykot, and Bruce Benz, pp. 275-287. Elsevier, San Diego.

2007 The Stable- and Radio-Isotope Chemistry of Western Basketmaker Burials: Implications for Early Puebloan Diets and Origins. American Antiquity 72(2):301-321.

Diederichs, Shanna R.

2016 Basketmaker III Colonization and the San Juan Frontier. Unpublished M.A. thesis, Northern Arizona University, Flagstaff.

Fetterman, Jerry, and Linda Honeycutt

1987 The Mockingbird Mesa Survey, Southwestern Colorado. Cultural Resource Series, no. 22. Bureau of Land Management, Denver.

Hayes, Alden C., and James A. Lancaster

1975 Badger House Community, Mesa Verde National Park. Publications in Archeology No. 7E. Wetherill Mesa Studies. National Park Service, Washington, D.C.

Heilen, Michael, and Jeffrey H. Altschul

2013 The Accuracy and Adequacy of In-Field Artifact Analysis: An Experimental Test at Two Archaeological Sites in the Western United States. Advances in Archaeological Practice 1(2):121-138.

Heitman, Carrie C.

2015 The House of Our Ancestors: New Research on the Prehistory of Chaco Canyon, New Mexico, A.D. 8001200. In Chaco Revisited: New Research on the Prehistory of Chaco Canyon, New Mexico, edited by Carrie C. Heitman and Stephen Plog, pp. 215-248. University of Arizona Press, Tucson.

Horn, Jonathan

2004 Landscape-Level History of the Canyons of the Ancients National Monument Montezuma and Dolores Counties, Colorado. Electronic document, http://www. blm.gov/style/medialib/blm/co/nm/canm/CANM
Documents.Par.87163.File.dat/Ancients\%20Report.pdf, accessed September 8, 2015.

Hovezak, Timothy D., and Leslie M. Sesler

2004 Cultural Resource Survey of the Chimney Rock Forest Health Initiative Project Area, San Juan National Forest, Pagosa Ranger District, Archuleta County, Colorado. La Plata Archaeological Consultants, Inc., Dolores, Colorado.

Hovezak, Timothy D., and Leslie M. Sesler

2006 New Data on Northwest New Mexico's Los Pinos Phase: A Classic Basketmaker II Occupation? Kiva 72(2):239-258.

Kantner, John

2010 Identifying the Pathways to Permanent Leadership. In The Evolution of Leadership: Transitions in Decision Making from Small-Scale to Middle-Range Societies, edited by Kevin J. Vaughn, Jelmer W. Eerkens, and John Kantner, pp. 249-281. School for Advanced Research Press, Santa Fe.

2012 The Early Pueblo Period: A Synthesis of Sorts. In Crucible of Pueblos: The Early Pueblo Period in the Northern Southwest, edited by Richard H. Wilshusen, Gregson Schachner, and James R. Allison, pp. 223-233. Cotsen Institute of Archaeology Press, University of California, Los Angeles.

Kidder, Alfred V.

1927 Southwestern Archaeological Conference. Science 66:489-491.

Kohler, Timothy A.

1993 New from the Northern American Southwest: Prehistory on the Edge of Chaos. Journal of Archaeological Research 1(4):267-321.

Kohler, Timothy A., Denton Cockburn, Paul L. Hooper, R. Kyle Bocinsky, and Ziad Kobti

2012 The Coevolution of Group Size and Leadership: An Agent-Based Public Goods Model for Prehispanic Pueblo Societies. Advances in Complex Systems 15, 115007:1-29.

Kohler, Timothy A., and Matt Glaude

2008 The Timing and Nature of the Neolithic Demographic Transition in the North American Southwest. In The Neolithic Demographic Transition and Its Consequences, edited by Jean-Pierre Bocquet-Appel and Ofer Bar Yosef, pp. 81-103. Springer, Berlin.

Kohler, Timothy A., Matt Pier Glaude, Jean-Pierre BocquetAppel, and Brian M. Kemp

2008 The Neolithic Demographic Transition in the U.S. Southwest. American Antiquity 73:645-669.

Kohler, Timothy A., Scott G. Ortman, Katie E. Grundtisch, Carly Fitzpatrick, and Sarah M. Cole

2014 The Better Angels of Their Nature: Declining Violence through Time among Prehispanic Farmers of the Southwest. American Antiquity 79:444-464.

Kohler, Timothy A., and Charles Reed

2011 Explaining the Structure and Timing of Formation of Pueblo I Villages in the Northern U.S. Southwest. In Sustainable Lifeways: Cultural Persistence in an Everchanging Environment, edited by Naomi F. Miller, Katherine M. Moore, and Kathleen Ryan, pp. 150-179. University of Pennsylvania, Philadelphia. 
Wilshusen

Kohler, Timothy A., and Kelsey M. Reese

2015 Long and Spatially Variable Neolithic Demographic Transition in the North American Southwest. Proceedings of the National Academy of Science 111(28):10,10110,106 .

Kohler, Timothy A., and Mark D. Varien

2010 A Scale Model of Seven Hundred Years of Farming Settlements in Southwestern Colorado. In Becoming Villagers: Comparing Early Village Societies, edited by Matthew S. Bandy and Jake R. Fox, pp. 37-61. University of Arizona Press, Tucson.

Komar, Debra

2008 Patterns of Mortuary Practice Associated with Genocide. Current Anthropology 49(1):123-133.

Lévi-Strauss, Claude

1982 The Way of the Mask. University of Washington Press, Seattle.

Lightfoot, Ricky R.

1988 Roofing an Early Anasazi Great Kiva: Analysis of an Architectural Model. Kiva 53:253-272.

Lightfoot, Ricky R., Richard H. Wilshusen, and Mark D. Varien

2014 Defining and Using Households in Archaeological Analysis. In Bulletin of the Texas Archaeological Society, Volume 85, edited by Tamra L. Walter, Timothy K. Perttula, and Nancy A. Kenmotsu, pp. 225-234. Austin, Texas.

Lipe, William D.

1999 Introduction. In Colorado Prehistory: A Context for the Southern Colorado Drainage Basin, edited by William D. Lipe, Mark D. Varien, and Richard H. Wilshusen, pp. 1-13. Colorado Council of Professional Archaeologists, Denver.

Lipe, William D., Mark D. Varien, and Richard H. Wilshusen (editors)

1999 Colorado Prehistory: A Context for the Southern Colorado Drainage Basin. Colorado Council of Professional Archaeologists, Denver. Distributed by the University of Utah Press.

Matson, R. G.

2003 The Spread of Maize into the U.S. Southwest. In Examining the Farming/Language Dispersal Process, edited by Peter Bellwood and Colin Renfrew, pp. 341356. McDonald Institute for Archaeological Research, University of Cambridge, Cambridge.

Matson, R. G., and Brian Chisholm

1991 Basketmaker II Subsistence: Carbon Isotopes and Other Dietary Indicators from Cedar Mesa, Utah. American Antiquity 56:444-459.

Mills, Barbara J.

2015 Unpacking the House: Ritual Practice and Social Networks at Chaco. In Chaco Revisited: New Research on the Prehistory of Chaco Canyon, New Mexico, edited by Carrie C. Heitman and Stephen Plog, pp. 249-271. University of Arizona Press, Tucson.

Mitchell, Mark D.

2005 The Archaeology of 5MT1, Stevenson and Porter Areas. The Yellow Jacket Project: Reports, Collections, and History. University of Colorado Museum, Boulder. Electronic document, http://yellowjacket.colorado. edu/5MT1.html, accessed September 11, 2005.
How Agriculture Took Hold in the Mesa Verde Region

2006 Research Traditions, Public Policy, and the Underdevelopment of Theory in Plains Archaeology: Tracing the Legacy of the Missouri Basin Project. American Antiquity 71(2):381-396.

Ortman, Scott G.

2006 Ancient Pottery of the Mesa Verde Country: How Ancestral Pueblo People Made It, Used It, and Thought about It. In The Mesa Verde World: Explorations in Ancestral Pueblo Archaeology, edited by David Grant Noble, pp. 101-109. School of American Research Press, Santa Fe, New Mexico.

Ortman, Scott G., Shanna Diederichs, Kari Schleher, Jerry Fetterman, Marcus Espinosa, and Caitlin Sommer

2016 Demographic and Social Dimensions of the Neolithic Revolution in Southwest Colorado. Kiva 82(3):232-258.

Ortman, Scott G., Mark D. Varien, and Lee Gripp

2007 Empirical Bayesian Methods for Archaeological Survey Data: An Application from the Mesa Verde Region. American Antiquity 72:241-272.

Potter, James M.

2009 Hunting and Early Pueblo Cuisine: Faunal Patterns among Early Villages in the Northern Southwest. In Animas-La Plata Project, Vol. XIII: Special Studies, edited by James M. Potter, pp. 191-214. Anthropological Research Paper No. 10, Vol. XIII. SWCA, Environmental Consultants, Phoenix.

2012 The Hunter and the Hunted: What Faunal Remains Reveal about Early Pueblo Village Cuisine, Ritual Organization, and Social Power. In Crucible of Pueblos: The Early Pueblo Period in the Northern Southwest, edited by Richard H. Wilshusen, Gregson Schachner, and James R. Allison, pp. 146-158. Cotsen Institute of Archaeology Press, University of California, Los Angeles.

Potter, James M. (editor)

2008 Animas-La Plata Project, Vol. IX: Ridges Basin Excavations-Archaic, Basketmaker II, and Limited Activity Sites. SWCA Anthropological Research Paper No. 10. SWCA Environmental Consultants, Phoenix.

2010 Animas-La Plata Project, Vol. XVI: Final Synthetic Report. SWCA Anthropological Research Paper No. 10. SWCA Environmental Consultants, Phoenix.

Potter, James M., and Jason P. Chuipka

2007 Early Pueblo Communities and Cultural Diversity in the Durango Area: Preliminary Results from the Animas-La Plata Project. Kiva 72:407-430.

2010 Perimortem Mutilation of Human Remains in an Early Village in the American Southwest: A Case for Ethnic Violence. Journal of Anthropological Archaeology 29:507-523.

Potter, James M., Jason P. Chuipka, and Jerry Fetterman

2012 The Eastern Mesa Verde Region: Migrants, Cultural Diversity, and Violence in the East. In Crucible of Pueblos: The Early Pueblo Period in the Northern Southwest, edited by Richard H. Wilshusen, Gregson Schachner, and James R. Allison, pp. 53-71. Cotsen Institute of Archaeology Press, University of California, Los Angeles.

Potter, James M., and Elizabeth M. Perry

2011 Mortuary Features and Identity Construction in an Early Village Community in the American Southwest. 
American Antiquity 76:529-546.

Potter, James M., and Thomas D. Yoder (editors)

2008a Animas-La Plata Project, Vol. II: Ridges

Basin Excavations-North-central Sites. SWCA

Anthropological Research Paper No. 10. SWCA

Environmental Consultants, Phoenix.

2008b Animas-La Plata Project, Vol. VIII: Ridges Basin

Excavations-Western Sites. SWCA Anthropological

Research Paper No. 10. SWCA Environmental

Consultants, Phoenix.

Potter, James M., and Thomas D. Yoder

2008c Space, Houses, and Bodies: Identity Construction and Destruction in an Early Pueblo Community. In The Social Construction of Communities: Structure, Agency, and Identity in the Prehispanic Southwest, edited by Mark D. Varien and James M. Potter, pp. 21-39. AltaMira Press, Walnut Creek, California.

Schachner, Gregson, Kellam Throgmorton, Richard H. Wilshusen, and James R. Allison

2012 Early Pueblos in the American Southwest: The Loss of Innocence and the Origins of the Early Southwestern Village. In Crucible of Pueblos: The Early Pueblo Period in the Northern Southwest, edited by Richard H. Wilshusen, Gregson Schachner, and James R. Allison, pp. 1-13. Cotsen Institute of Archaeology, University of California, Los Angeles.

Schlanger, Sarah H.

1988 Patterns of Population Movement and Long-Term Population Growth in Southwestern Colorado. American Antiquity 53(4):773-793.

Schlanger, Sarah, Richard H. Wilshusen, and Heidi Roberts

2015 From Mining Sites to Mining Data: Archaeology's Future. Kiva 81(1-2):80-99.

Schwindt, Dylan M., R. Kyle Bocinsky, Scott G. Ortman, Donna M. Glowacki, Mark D. Varien, and Timothy A. Kohler

2016 Social Consequences of Climate Change in the Northern Southwest. American Antiquity 81(1):74-96.

Sesler, Leslie M., and Timothy D. Hovezak

2011 Farming at the Edge of Paradise: Basketmaker II Emergence in New Mexico's San Juan Basin. Southwestern Lore 77(2-3):9-20.

Shennan, Stephen, Sean S. Downey, Adrian Timpson, Kevan Edinborough, Sue Colledge, Tim Kerig, Katie Manning, and Mark G. Thomas

2013 Regional Population Collapse Followed Initial Agriculture Booms in Mid-Holocene Europe. Nature Communications 4:2486. DOI:10.1038/ncomms3486, accessed April 22, 2018.

Sommer, Caitlin A., Shanna R. Diederichs, Susan C. Ryan, Steven R. Copeland, and Kari L. Schleher

2015 The Basketmaker Communities Project Annual Report, 2014 Field Season. Available at: http://www.crowcanyon.org/ResearchReports/ BasketmakerCommunities/interim_reports/2014/ text 2014.pdf, accessed April 2, 2018.

Van Dyke, Ruth M.

2007 The Chaco Experience: Landscape and Ideology at the Center Place. School for Advanced Research Press, Santa Fe.
Varien, Mark D., and Shanna R. Diederichs

2012 Nomination of the Indian Camp Ranch Archaeological District, Site 5MT19927, to the National Register of Historic Places. Accepted and listed on the National Register of Historic Places, National Park Service, Washington, D.C.

Varien, Mark D., Scott G. Ortman, Timothy A. Kohler, Donna M. Glowacki, and C. David Johnson

2007 Historical Ecology in the Mesa Verde Region: Results from the Village Ecodynamics Project. American Antiquity 72:273-300.

Walker, William $\mathrm{H}$.

2008 Witches, Practice, and the Context of Pueblo Cannibalism. In Social Violence in the Prehispanic Southwest, edited by Deborah L. Nichols and Patricia L. Crown, pp. 143-216. University of Arizona Press, Tucson.

Ware, John A.

2014 A Pueblo Social History: Kinship, Sodality, and Community in the Northern Southwest. School for Advanced Research Press, Santa Fe.

Webster, Laurie D.

2012 The Perishable Side of Early Pueblo Style and Identity: Textiles, Sandals, and Baskets. In Crucible of Pueblos: The Early Pueblo Period in the Northern Southwest, edited by Richard H. Wilshusen, Gregson Schachner, and James R. Allison, pp. 159-184. Cotsen Institute of Archaeology, University of California, Los Angeles.

Wilshusen, Richard H.

1986 The Relationship between Abandonment Mode and Ritual Use in Pueblo I Anasazi Protokivas. Journal of Field Archaeology 13:245-254.

1999a Basketmaker III (A.D. 600-750). In Colorado Prehistory: A Context for the Southern Colorado Drainage Basin, edited by William D. Lipe, Mark D. Varien, and Richard H. Wilshusen, pp. 166-195. Colorado Council of Professional Archaeologists, Denver.

1999b Pueblo I (A.D. 750-900). In Colorado Prehistory: A Context for the Southern Colorado Drainage Basin, edited by William D. Lipe, Mark D. Varien, and Richard H. Wilshusen, pp. 196-241. Colorado Council of Professional Archaeologists, Denver.

2009 Late Basketmaker and Early Pueblo Landscapes in the Animas-La Plata and Piedra Archaeological Districts: A Review of Archaeological Work and Settlement Patterning East of the Animas River. In Animas-La Plata Project, Vol. XIII: Special Studies, edited by James M. Potter, pp. 5-42. SWCA Anthropological Research Paper No. 10. SWCA Environmental Consultants, Phoenix.

2015 Chaco's Beginnings: What We Know Now, and What to Do Next. In Early Puebloan Occupations in the Chaco Region, Volume I: Excavations and Survey of Basketmaker III and Pueblo I Sites, Chaco Canyon, New Mexico, edited by Thomas C. Windes, pp. 745-761. Arizona State Museum Archaeological Series 210. University of Arizona, Tucson.

2017 Early Pueblo Great House Communities and Their Leaders: The Transformation of Community Leadership in the Mesa Verde and Chaco Regions, A.D. 625-1025. 
In Feast, Famine, or Fighting? Multiple Pathways to Social Complexity, edited by Richard J. Chacon and Ruben G. Mendoza, pp. 249-267. Springer International, New York.

Wilshusen, Richard H., Michael Heilen, Wade Catts, Karyn de Dufour, and Brad Jones

2016 Archaeological Survey Data Quality, Durability, and Use: Findings and Recommendations. Advances in Archaeological Practice 4(2):106-117.

Wilshusen, Richard H., Winston Hurst, and Jason Chuipka

2012 Small Hamlets to Early Great Houses: The Emergence of Villages in the Mesa Verde Region between A.D. 200 and 900. In Southwestern Pithouse Communities, A.D. 200-900, edited by Lisa C. Young and Sarah A. Herr, pp. 141-153. University of Arizona Press, Tucson.

Wilshusen, Richard H. and Scott G. Ortman

1999 Rethinking the Pueblo I Period in the San Juan Drainage: Aggregation, Mitigation, and Cultural Diversity. Kiva 64(3):369-399.

Wilshusen, Richard H., Scott G. Ortman, and Ann Phillips

2012 Processions, Leaders, and Gathering Places: Changes in Early Pueblo Community Organization as Seen in Architecture, Rock Art, and Language. In Crucible of Pueblos: The Early Pueblo Period in the Northern Southwest, edited by Richard H. Wilshusen, Gregson Schachner, and James R. Allison, pp. 198-218. Cotsen Institute of Archaeology, University of California, Los Angeles.

Wilshusen, Richard H., Scott G. Ortman, Shanna Diederichs, Donna M. Glowacki, and Grant Coffey

2012 Heartland of the Early Pueblos: The Central Mesa Verde. In Crucible of Pueblos: The Early Pueblo Period in the Northern Southwest, edited by Richard H. Wilshusen, Gregson Schachner, and James R. Allison, pp. 14-34. Cotsen Institute of Archaeology, University of California, Los Angeles.

Wilshusen, Richard H. and Elizabeth M. Perry

2008 Evaluating the Emergence of Early Villages in the North American Southwest in Light of the Proposed Neolithic Demographic Transition. In The Neolithic Demographic Transition and its Consequences, edited by Jean-Pierre Bocquet-Appel and Ofer Bar-Yosef, pp.417438. Springer, Berlin.

2012 Women's Central Role in Early Pueblo Change: Ground Stone, Archaeobotanical, Ceramic, Architectural, and Skeletal Evidence. In Crucible of Pueblos: The Early Pueblo Period in the Northern Southwest, edited by Richard H. Wilshusen, Gregson Schachner, and James R. Allison, pp. 185-197. Cotsen Institute of Archaeology, University of California, Los Angeles.

Wilshusen, Richard H., and James D. Potter

2010 The Emergence of Early Villages in the American Southwest: Cultural Issues and Historical Perspectives. In Becoming Villagers: Comparing Early Village Societies, edited by Matthew S. Bandy and Jake R. Fox, pp. 165183. University of Arizona Press, Tucson.
Wilshusen, Richard H., Gregson Schachner, and James R. Allison (editors)

2012 Crucible of Pueblos: The Early Pueblo Period in the Northern Southwest. Cotsen Institute of Archaeology, University of California, Los Angeles.

Wilshusen, Richard H., and Ruth Van Dyke

2006 Chaco's Beginnings: The Collapse of Pueblo I Villages and the Origins of the Chaco System. In The Archaeology of Chaco Canyon: An 11th Century Pueblo Regional Center, edited by Stephen H. Lekson, pp. 211259. School of American Research Press, Santa Fe.

Wilshusen, Richard H., and C. Dean Wilson

1995 Reformatting the Social Landscape in the Late Pueblo I-Early Pueblo II Period: The Cedar Hill Data in Regional Context. In The Cedar Hill Special Treatment Project: Late Pueblo I, Early Navajo, and Historic Occupations in Northwestern New Mexico, compiled by Richard H. Wilshusen, pp. 43-80. La Plata Archaeological Consultants Research Papers No. 1. Dolores, Colorado.

Windes, Thomas C.

2004 The Rise of Early Chacoan Great Houses. In In Search of Chaco: New Approaches to an Archaeological Enigma, edited by David Grant Noble, pp. 14-21. School of American Research, Santa Fe.

2007 Gearing Up and Piling On: Early Great Houses in the Interior San Juan Basin. In The Architecture of Chaco Canyon, New Mexico, edited by Stephen H. Lekson, pp. 45-92. University of Utah Press, Salt Lake City.

2015 Early Greathouse Beginnings. In Early Puebloan Occupations in the Chaco Region, Volume I: Excavations and Survey of Basketmaker III and Pueblo I Sites, Chaco Canyon, New Mexico, edited by Thomas C. Windes, pp. 663-744. Arizona State Museum Archaeological Series 210. University of Arizona, Tucson.

Yoder, Thomas D., and James M. Potter (editors)

2007 Animas-La Plata Project, Vol. IV: Ridges Basin Excavations-Eastern Basin Sites. SWCA Anthropological Research Paper No. 10. SWCA Environmental Consultants, Phoenix.

\section{Contributor Notes}

Richard Wilshusen (Ph.D. University of Colorado) has 40 years of experience as a field archaeologist, instructor, curator, contractor, and administrator. He has worked with universities, cultural resource management firms, state and federal government, and tribes. Wilshusen is best known for his research on public archaeology, early Pueblo village formation, Southwestern migration pathways, early great house communities, and Navajo ethnogenesis. He was originally trained as a cultural anthropologist, but has made his living as an archaeologist.

ORCiD

https://orcid.org/0000-0002-4708-3232 
